\title{
Historical changes in the shoreline and management of Marawila Beach, Sri Lanka, from 1980 to 2017
}

\section{Introduction}

The erosion of sandy shorelines poses a serious hazard to life and property in coastal regions. In the past, shoreline management solutions were often implemented without considering the chronological changes of the threatened coast (Roebeling et al., 2011). Such shoreline management solutions could potentially influence both socioeconomic and environmental processes. Hence, adaptive management (Williams et al., 2009) strategies are commonly implemented for such erosive beaches (Klein et al., 1998; Paganelli et al., 2013; Turner et al., 1998; Uda, 2017). Chronological shoreline and bathymetric data collection is required from feedback loops through field observation to enable successful adaptive shoreline management, although such data are either limited or difficult to access in many developing countries due to a lack of budget, technical expertise, and weak institutional structure (Kamaladasa, 2008a, 2008b; Karunaratne, 2011; Walters, 1997)

Sri Lanka is a tropical island country, and its coastal areas are valuable for tourism, fisheries, and logistics; thus, protecting and the sound management of coasts are important. In addition to tsunami disaster mitigation(Ratnasooriya et al., 2007; Samarasekara et al., 2017), erosion is one of the most serious problems associated with coastal management (CC\&CRMD, 2006; Wickramaarachchi, 2012).

Coastal erosion is a long-term problem in Sri Lanka, and approximately two billion Sri Lankan rupees (approximately 13 million US dollars) have been invested in erosion management up to 2017. The Coast Conservation Department (CCD), a governmental department that manages and conserves the Sri Lankan coast, was established to enact the Coast Conservation Act No. 57 of 1981 in 1984. The CCD completed the first coastal erosion assessment presented in the Master Plan for Coastal Erosion Management (MPCEM) of 1986 (Dayananda, 1992; Godage, 1992; Perera, 1990a). The first coastal zone management plan (CZMP) was prepared and implemented by the CCD in 1990 (CC\&CRMD, 2015). A coastal resource management project (CRMP) was allocated a budget for conducting coastal stabilization efforts during 2000 - 2006. The CZMP was revised in 2004 and constituted an extraordinary gazette in 2006 (CC\&CRMD, 2006). The CCD was further explanted into the Coast Conservation and Coastal Resource Management Department (CC\&CRMD) to conserve the coastal zone and sustainably manage coastal resources in 2009. Only the erosion of the southwestern coast has been investigated in detail (Dayananda, 1992; Godage, 1992; Perera, 1990b; Sheffer and Frohle, 1991; Wickramaarachchi, 2012), and even the coastal erosion hazard profile, which was published by the Ministry of Disaster Management in 2012, focused on this area as it is the most densely populated coast of Sri Lanka.

Marawila Beach is a sandy linear beach on the north-western coast of Sri Lanka, facing the Indian Ocean. A maximum erosion rate of 10-12 m/yr was recorded during 1991 - 1999 (CC\&CRMD, 2006) while the coast was functioning as a tourist destination and nearshore fishing ground. Following the event, the CC\&CRMD introduced several different management solutions to conserve the shoreline considering differences in the usages of the threatened coasts as well as the results of the solutions. Therefore, this case study is a good example of an investigation into chronological changes in beach morphology from 
multiple perspectives. Researchers recently studied the system degradation 46 (Samarawikrama et al., 2009; Wickramaarachchi, 2011) of the Maha River and discussed the erosion of beaches on the western coast, including Marawila. However, the heuristic literature on the devastating erosion of Marawila Beach is still limited; therefore, we attempted to coordinate different governmental institutes to obtain unpublished data.

This study aimed to determine the chronological changes of adaptively managed erosive coasts when historical data are limited, focusing on Marawila Beach. More specifically, we estimated the accreted and eroded beach area at different years since 2002 using available satellite images; plotted the cross-shore beach profile change between 2007 and 2017 and then searched the causes and effects of each morphological states of Marawila beach. This first introduces the case study area and the methods followed. The chronological coastal morphology status is explained in the results section, and the causes and effects of each status and adaptation measures are explained in the discussion. This paper concludes by describing the adaptively managed erosive coast of Marawila. This study focuses on the historical shoreline changes and adopted management for approximately 40 years for one of the most vulnerable beaches in Sri Lanka.

\section{Methods}

\subsection{Study site and livelihood of residents}

The locations of Marawila Beach, Maha River, and the financial capital, Colombo, in Sri Lanka are shown in Figure 1. The mouth of the Maha River is located $13 \mathrm{~km}$ south of the beach, in the upstream of longshore drift during the south-west monsoon (Chandramohan et al., 1990; Dayananda, 1992; Sheffer and Frohle, 1991). The annual runoff of the Maha River is 958 million $\mathrm{m}^{3}$, and the basin covers $1,528 \mathrm{~km}^{2}$ (Bastiaanssen and Chandrapala, 2003). The severe erosion started around Maha River mouth and propagated towards north since 1980. The whole beach stretch up to Marawila from Maha river mouth was protected from detached breakwaters and revetments. The propagated erosion reached Marawila area in 2005 (Wickramaarachchi, 2011) and coastal managers successfully prevented the propagation of erosion further towards the north by using various shoreline management measures. It is observed that over management induces problems by hampering the normal pattern of the hydrodynamic processes and sediment circulations Figure 1 (left) shows the $6.5 \mathrm{~km}$ of the studied shoreline in January 2017, together with the spatial distributions of year-round hotels, boatyards, and various shoreline management solutions. Figure 2 presents images of the statues of these solutions from February 2017. 


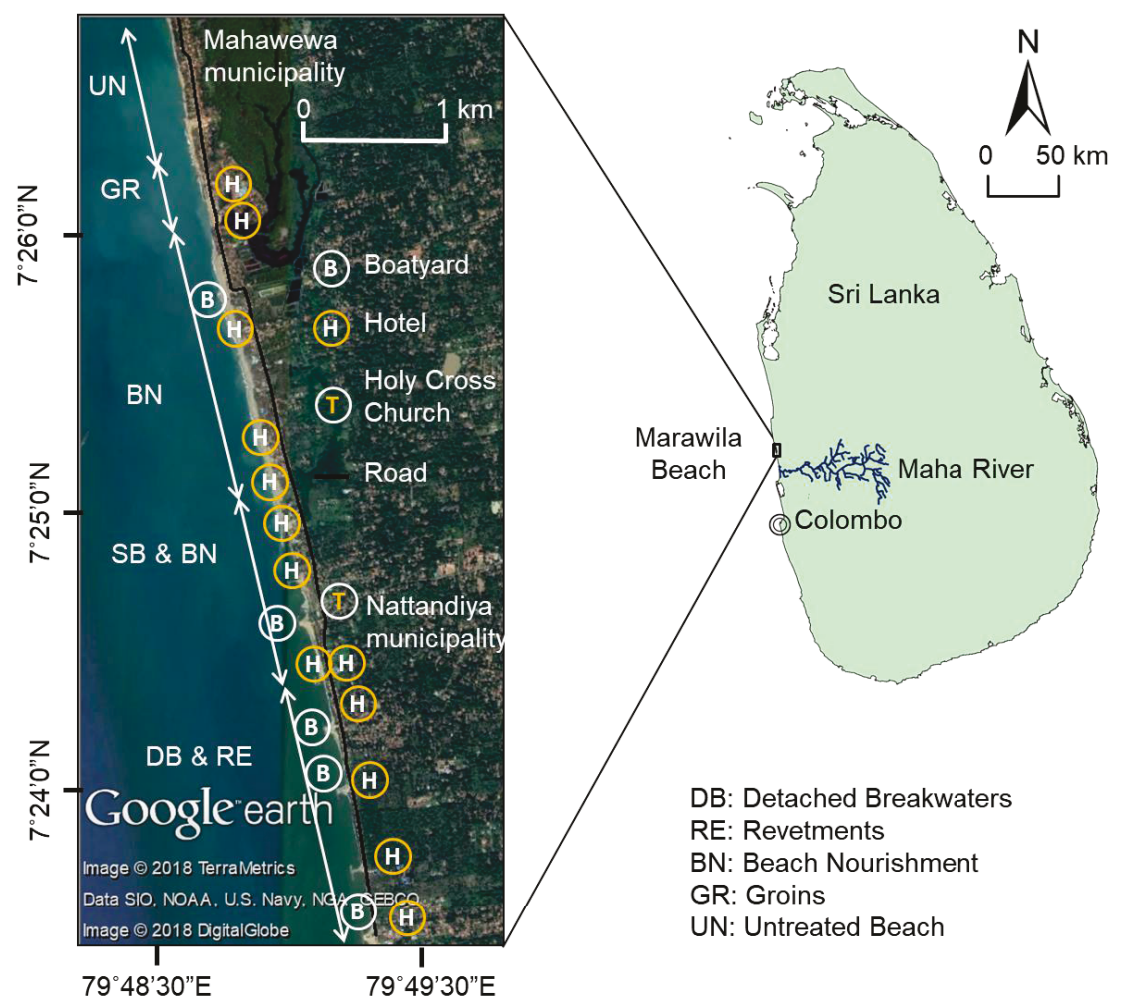

Figure 1: (Right) Spatial extent of Marawila Beach, Maha River and the financial capital, Colombo, in Sri Lanka (Left) Spatial distribution of year-around hotels, boatyards and various shoreline management solutions of studied shoreline in January 2017. (Source: Google Earth, Data SIO, NOAA, U.S. Navy, NGA, GEBCO (Photo was taken by Terra Metrics/Digital Globe satellite)
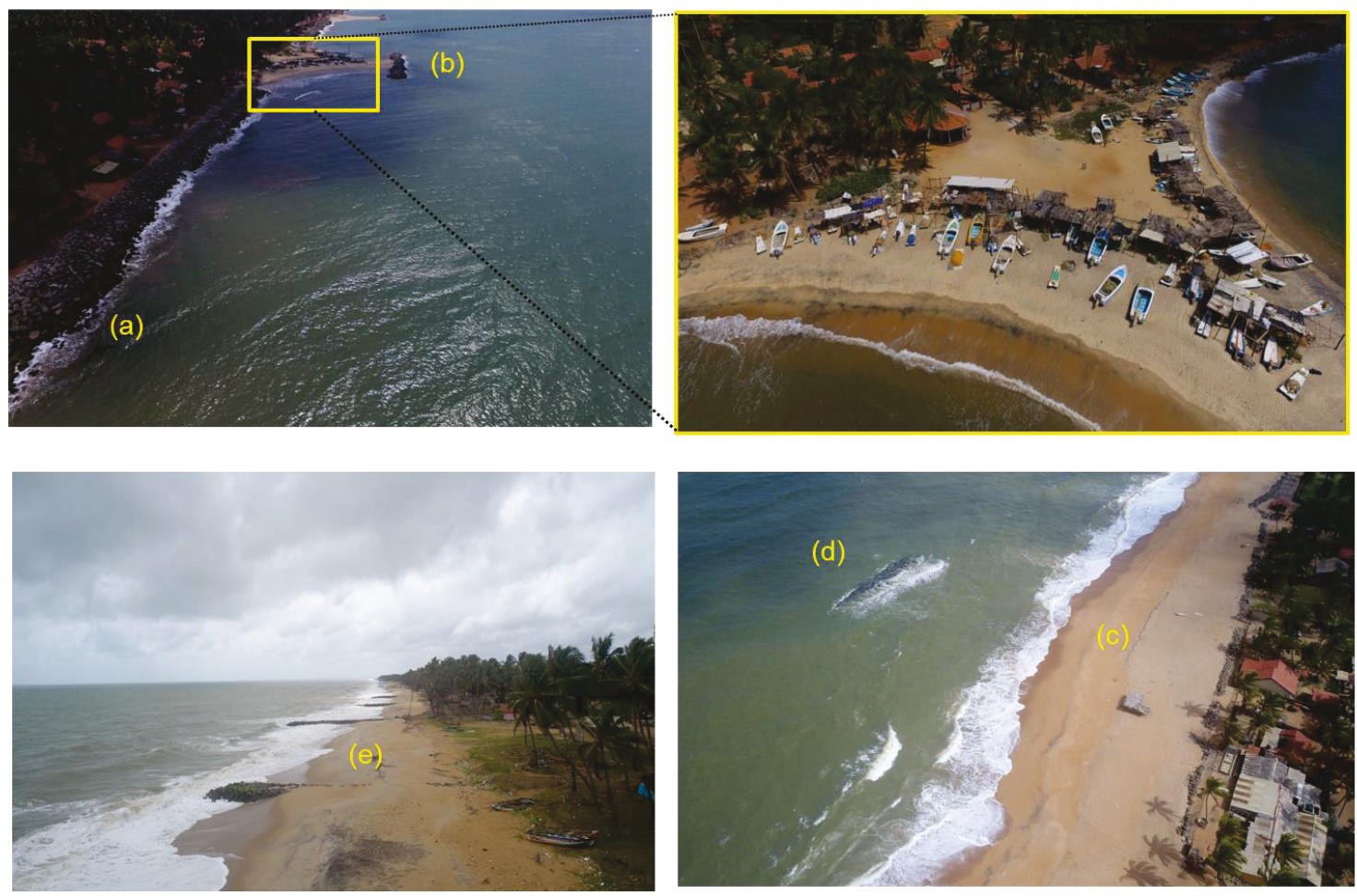

Figure 2: Pictures showing (a) revetment (b) detached breakwater (c) beach after sand nourishment (d) submerge breakwater and (e) groins of Marawila Beach in February 2017 
The southern $2.0 \mathrm{~km}$ stretch of the $6.5 \mathrm{~km}$ beach resides in the Nattandiya Municipality, and the remaining $4.5 \mathrm{~km}$ resides in the Mahawewa Municipality. The population densities of Nattandiya and Mahawewa are $820 / \mathrm{km}^{2}$ and $680 / \mathrm{km}^{2}$, respectively (DCS, 2012a). The tourism industry is well-established in this area, with the beach and Holy Cross Church serving as the main tourist attractions. A wide range of hotels have been established along the coast, thirteen of which operate throughout the year including, one 4-star and two 2-star hotels, and provide many direct and indirect job opportunities. Rental and taxi services are common among these indirect positions. Five boatyards (see Figure 1) shelter the small boats owned by nearshore fishermen who typically catch sardines, anchovies, ponyfishes, bigeye scads, squid, cuttlefish, flying fish, green tiger prawns, and crabs. The nearshore fishing industry provides a livelihood to the majority of permanent resident's livelihood. The wives or family members of fishermen usually sell their fish harvest at the beach. Nearshore fishing is difficult during the South-West monsoon period; therefore, some fishermen change their livelihood during this season. Security, driving, and masonry are the most popular seasonal occupations among such fishermen. Poultry and pig farming and fishnet weaving are the primary-secondary livelihoods of fishermen. Over ten small shops in this area sell snacks and souvenirs to both locals and tourists.

Migration overseas is a common pattern for searching job availabilities. Migrant workers remittance is one of a main foreign exchange remittance which was $8 \%$ of the country's GDP in 2015 (UNSL, 2015). Seventy percent Sri Lankans are Buddhists, while 7.4\% were Catholics (DCS, 2012b), who are mostly concentrated in north-western Sri Lanka. Most of the residents in Marawila Beach are Catholics, and Italy is one of their favorite destination (Pathirage and Collyer, 2011). Some of the migrated residents returned to Sri Lanka and invested in the fishery and tourism industries, while some residents still receive financial support from family members who migrated to Italy. Marawila area receives $1500-2000 \mathrm{~mm}$ of annual rainfall primarily during the southwestern monsoon (April and September); maximum temperature varies between $30^{\circ} \mathrm{C}$ and $32^{\circ} \mathrm{C}$ and minimum temperature varies between $22^{\circ} \mathrm{C}$ and $25^{\circ} \mathrm{C}$ (DoM, 2016). Marawila soil consists of sandy regosols (Panagos et al., 2011) and its geomorphological unit is up-warped Pleistocene coastal plain (Verstappen and Hoschtitzky, 1987). The significant wave heights induced by the sea and swell parts $\left(H_{m 0}\right)$ are in the range of $[1.1 \mathrm{~m}, 1.4 \mathrm{~m}]$ during the southwestern monsoon period.at $15 \mathrm{~m}$ water depth. $H_{m o}$ values are in the range of $[0.3 \mathrm{~m}, 0.6 \mathrm{~m}]$ during the off monsoon period (Gunaratna et al., 2011). Weekly mean wave direction $(\theta)$ of swell waves raged $\left[180^{\circ}, 220^{\circ}\right]$ throughout the year. $\theta$ values of sea waves ranged $\left[225^{\circ}, 270^{\circ}\right]$ during the monsoon period and $\left[90^{\circ}\right.$, $190^{\circ}$ ] during off monsoon period (Sheffer and Frohle, 1991).

\subsection{GIS analysis of satellite image}

The average shoreline position (considering average wave run-up value) of Marawila Beach was marked using polylines on visible Digital Globe satellite images in Google Earth Pro. Images were captured on April 26, 2002, December 29, 2005, November 11, 2011 , September 21, 2012, December 17, 2013, January 19, 2015, January 13, 2016, and January 12,2017 . Most of the cloud-free images were captured during non-monsoon seasons. These eight days were denoted from as $i=1,2 \ldots 8$, respectively. Each shoreline (indicated by the polylines) was converted into a geographic co-ordinate system (Kandawala_Sri_Lanka_Grid) from the projected co-ordinate system (GCS_WGS_1984). Each polyline was split into 6500 equidistant line segments (approximately $1 \mathrm{~m}$ in length) using ArcGIS - ESRI, and the coordinate of the mid-point of each segment was then extracted. These 6500 points were 
$A_{\Delta i, r}=\frac{d_{i+1, r}-d_{i, r}}{t_{i+1}-t_{i}}$

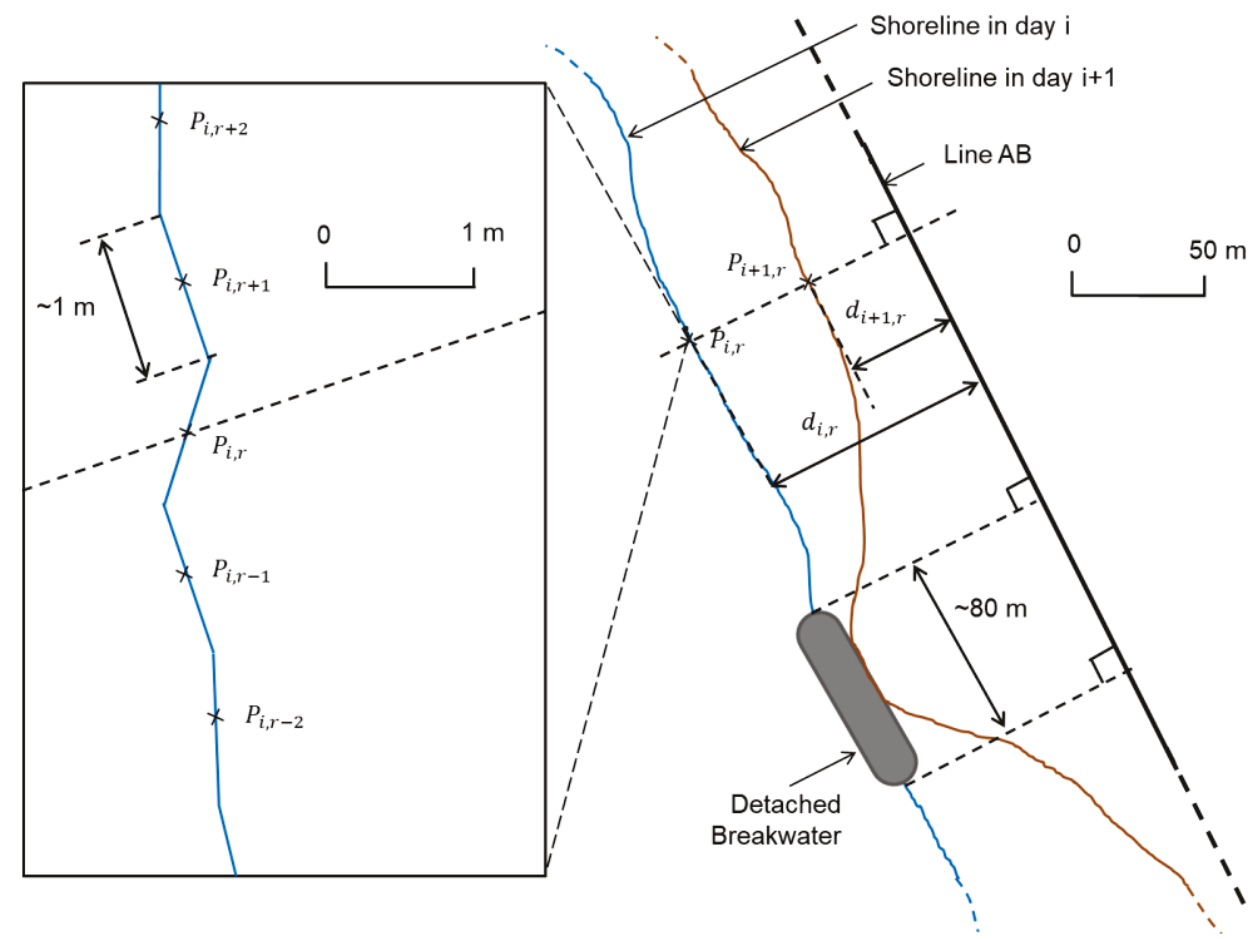

Figure 3: (Right) Schematic diagram of a plan view of the coastlines showing shoreline of day $i$, day $i+1, a$ detached breakwater, line $A B$ and point $P_{i, r}$ and $P_{i+1, r} . d_{i, r}$ and $d_{i+1, r}$ are perpendicular distances to line $A B$. from point $P_{i, r}$ and $P_{i+1, r}$ respectively (Left) Enlarged view of point $P_{i, r}$ which is the mid-point of equidistant line segments.

As the times at which the satellite images were captured were unknown, the shoreline marked upon them was not corrected for the effect of tides. The maximum error of shoreline positions can be obtained using Equation 3 . 
156 The maximum spring tidal range of Marawila Beach is $0.7 \mathrm{~m}( \pm 0.35 \mathrm{~m})$ (De Vos et al., 2014; 157 Fittschen et al., 1992). In February 2017, the minimum beach slope in the swash zone was 158 1:8. Furthermore, the slope between the $-2.0 \mathrm{~m}$ and $+2.0 \mathrm{~m}$ contour lines was measured 159 from topographic bathymetric survey and beach maps from February 2007, and the minimum slope was 1:9. Therefore, the maximum error for shoreline position was $\pm 0.6 \mathrm{~m}$

\subsection{Field observation and Interview survey}

We walked along the coastline and road of Marawila Beach on February 14 and 15, 2017 (see Figure 1 (Left)). The mouth of the Maha River was visited on February 22, 2017, and we then travelled $15 \mathrm{~km}$ upstream from the river mouth. The beach slope (in swash zone) was measured at several locations using a measuring staff and spirit level, and we also captured aerial images of the coastal structures using a drone (DJI Phantom 3 Professional) while we walked along the coastline.

A total of 26 coast users and three river users were interviewed using a set of a semistructured questionnaire for approximately one hour per person. The questions to the coast users focused on the history of the erosion problem and the respondent's perception of shoreline management measures. The questions to the river users focused on the history of degradation of the river and the respondent's perception of river basin management. We approached as many interviewees as possible during our visits to the study sites. The main objective of conducting several interviews was to provide cross-references to different coast users experiences of shoreline management. The different coast users were people who engaged in fishing industry, tourism industry, residents and tourists We interviewed four fishermen, three fishing union leaders, three residents, five tourists, three local shop owners, two taxi drivers, two hotel owners, and four hotel workers. Fishing unions were not apparently independent and they were associated with national political parties. We interviewed three leaders of such fishing unions. Few members of fishing unions were interviewed separately from the leaders to recognize if there are different opinions between them. The river users included two small-scale clay-brick manufactures and a manager of a large-scale clay mining site. Only seven of the 29 field interviewees were women, and all the interviewees were between 28 and 55 years of age. We have cited a few responses in the results section and rest of the interview results were used to explain the reasons of analytical results such as GIS analysis of shoreline change

In addition, interviews were conducted with two coastal managers of the CC\&CRMD (males) on February 23, 2017, and a coastal engineering academic (male) from the University of Moratuwa on February 12, 2017. These three interviews were conducted to investigate the economic and technical reasons behind the planning and construction of shoreline management structures as well as to verify the interview results of the beach and river users.

\subsection{Bathymetric survey}

A bathymetric survey of Marawila Beach was conducted $500 \mathrm{~m}$ offshore using an echo sounder (LOWRANCE Fishfinder HOOK4) on February 25 and 26, 2017. The transducer was fixed to an adjustable pole that was attached to the side of a small fishing boat. 
Figure 4-(a) shows the cruise lines for these surveys. Four of these cruise lines were $2 \mathrm{~km}$ long, while the others were $500 \mathrm{~m}$ long. The cruises were approximately perpendicular to the shoreline, and the depth of the water was measured every $400 \mathrm{~m}$. The measurements were corrected for tidal activity using a reef master sonar viewer. The five-points moving-average filter was applied to minimize the error caused by wave action.

Bathymetric and beach topography surveys (up to the 3-m contour line) were conducted by oceanographic and surveying professionals from the NARA (National Aquatic Resources Research and Development Agency, Sri Lanka) in February 2007. The bathymetric survey was conducted by cruising along lines at a water depth of $7.0-6.5 \mathrm{~m}$, which was measured every $200 \mathrm{~m}$. Figure 4-(a) also shows these survey cruise lines.

There were few similarities between the bathymetric survey lines from 2017 and 2007 (Figure 4-(a)), thus, a direct comparison was difficult. Two TIN (triangular irregular network) surfaces were created by linearly interpolating the datasets from 2007 and 2017 . Twelve 500-m long lines (Figure 4-(b)) were drawn perpendicular to the 2017 shoreline, and lines near to the 2017-survey cruise lines were selected to reduce errors caused by interpolation. The TIN surfaces were converted into raster images and the cell values (depth) of both raster images along each line were extracted using ArcGIS. The depth (cross-shore profile) was then plotted against the distance along each line.

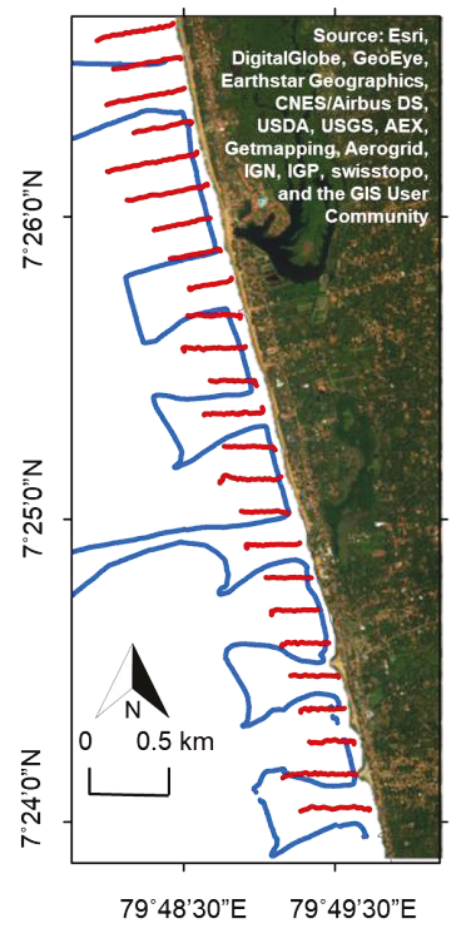

(a)

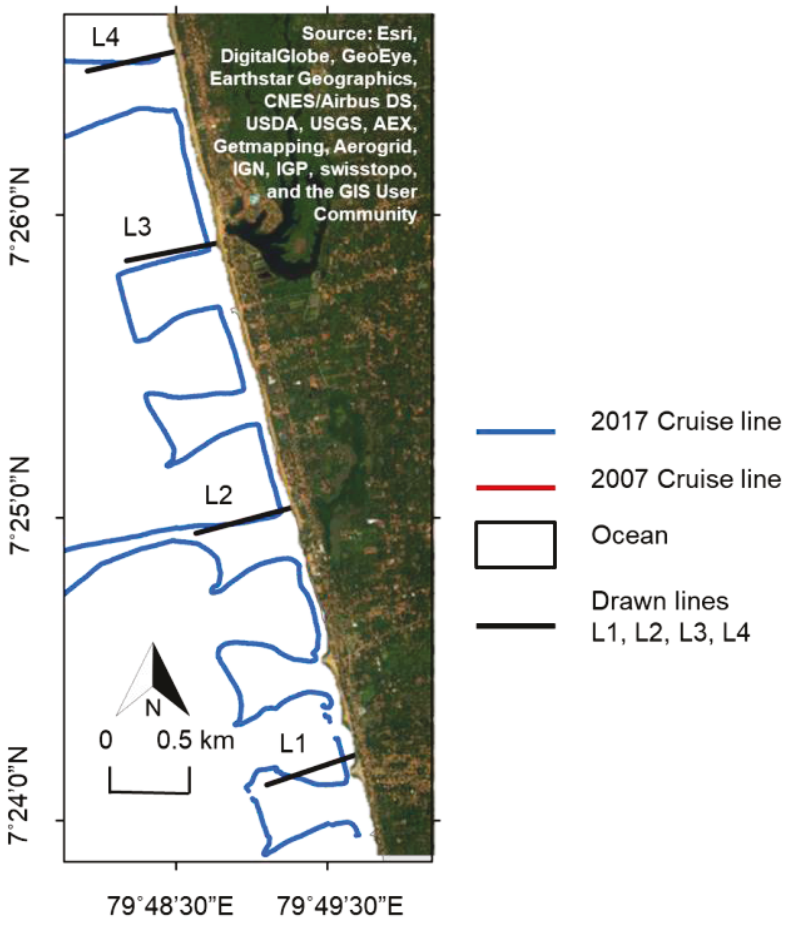

(b)

Figure 4: Maps showing (a) boat cruise lines of bathymetry survey 2017 and 2007 (b) adjusted lines (L1, L2, L3, and L4) to compare cross-shore profiles of 2017 and 2007 (Source: Esri, DigitalGlobe, GeoEye, Earthstar Geographics, CNES/Airbus DS, USDA, USGS, AEX, Getmapping, Aerogrid, IGN, IGP, swisstop o, and the GIS User Community )

\section{Results}


221 Figure 5 represents a time series of the annual beach accretion and erosion rates estimated 222 from the selected satellite images with information regarding the implementation of several 223 shoreline management measures along the Marawila Beach. The uncertainty bound due to 224 tidal effect was marked in dotted lines in each graph.
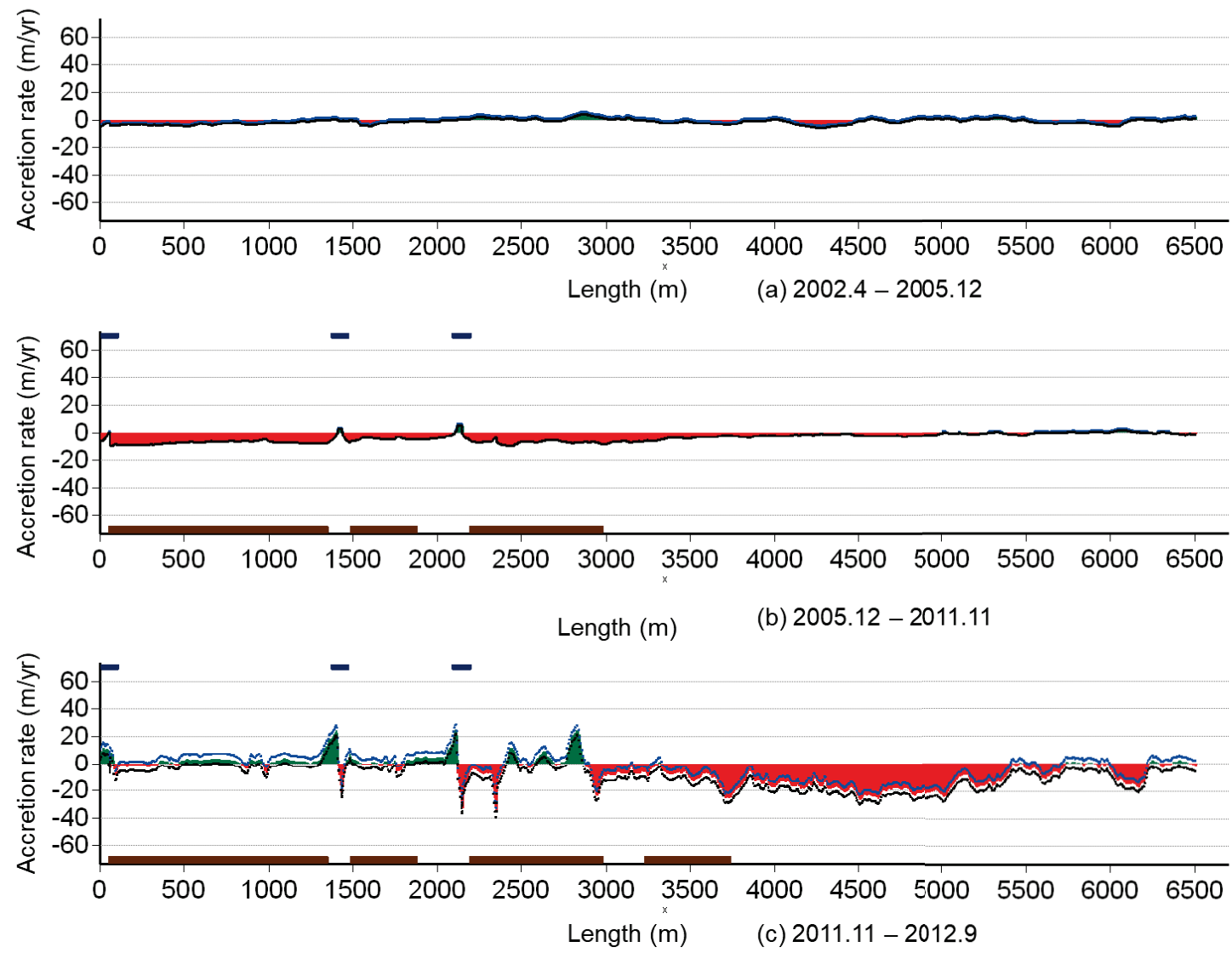

225
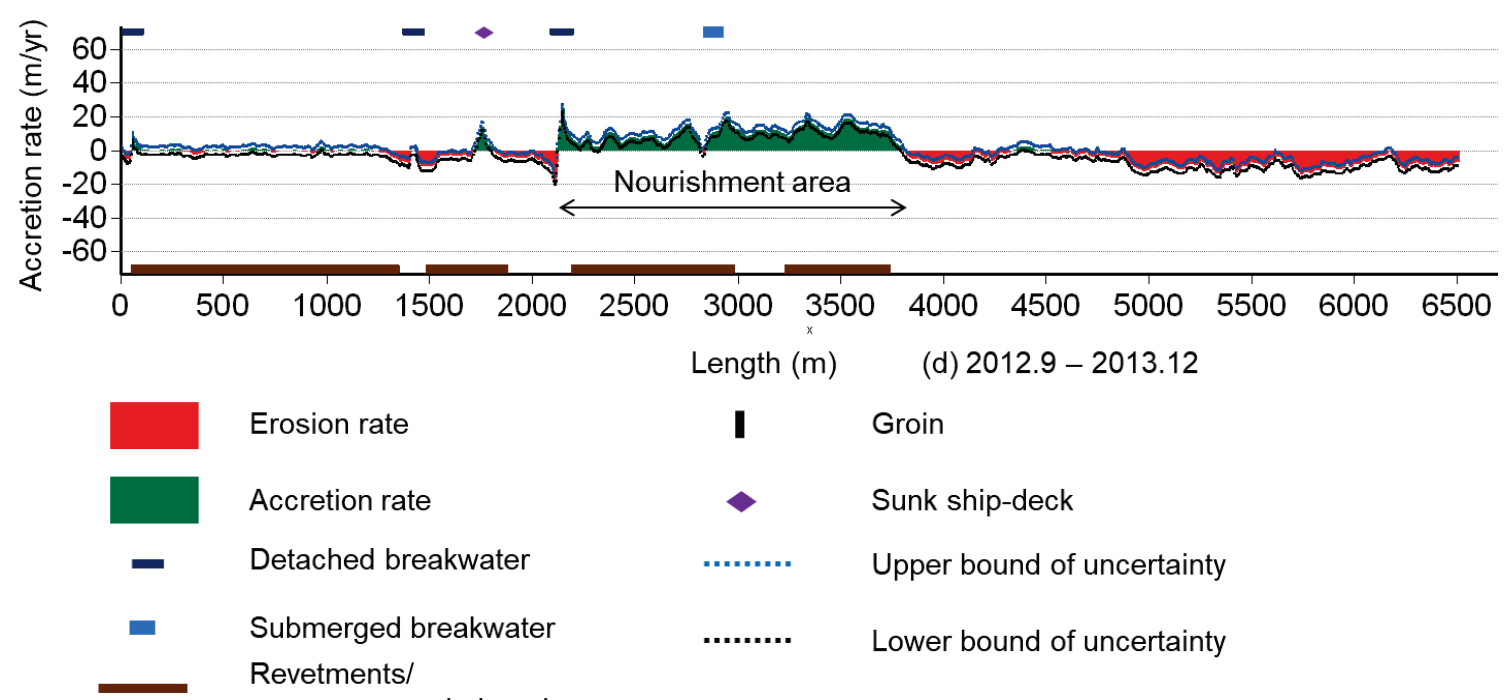

Erosion rate

Groin

Accretion rate

Sunk ship-deck

Detached breakwater

Upper bound of uncertainty

- Submerged breakwater

Revetments/

emergency rock dumping

Figure 5: Annual rate of beach accretion/ erosion (showing both the accretion and the erosion rate) between (a) April 26, 2002 and December 29, 2005 (b) December 29, 2005 and November 11, 2011 (c) November 11, 2011 and September 21, 2012 (d) September 21, 2012 and December 17, 2013, with records of implementation of shoreline management measures in Marawila Beach (continued) 


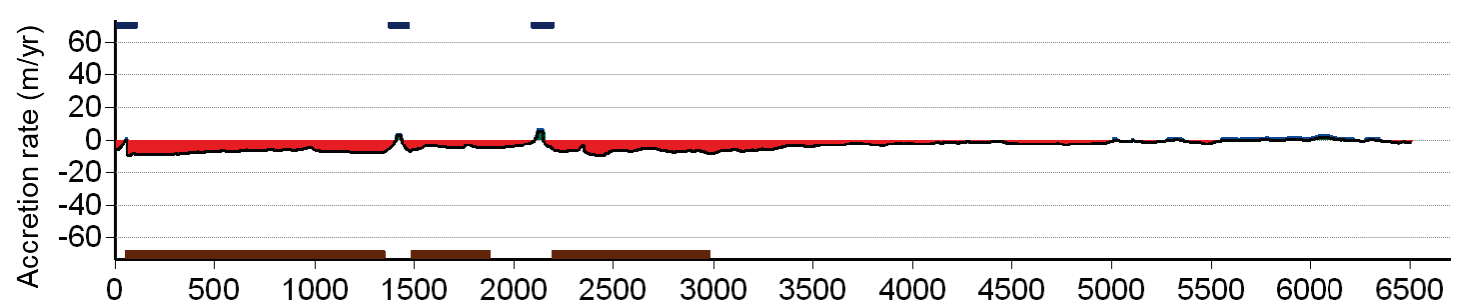

Length ( $m$ )

(b) $2005.12-2011.11$
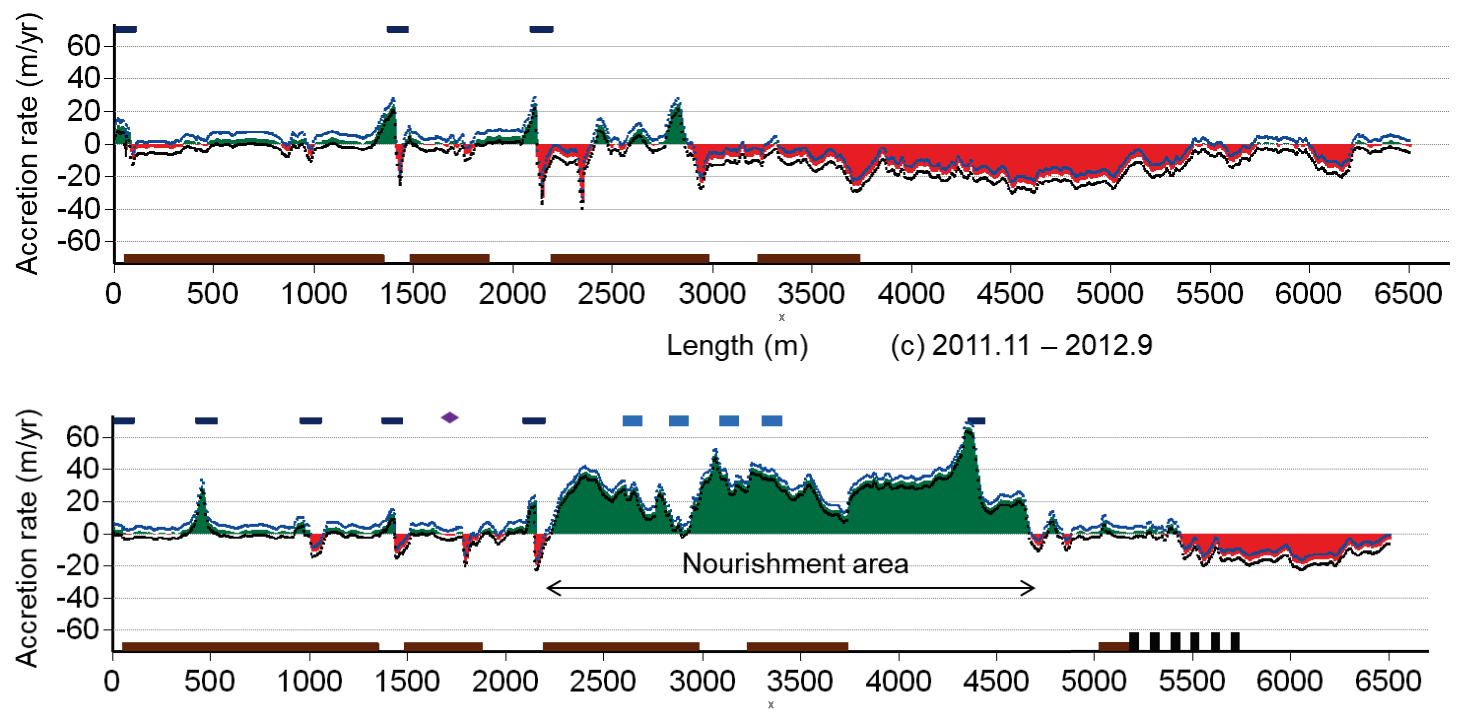

Length $(\mathrm{m})$

(g) $2016.1-2017.1$

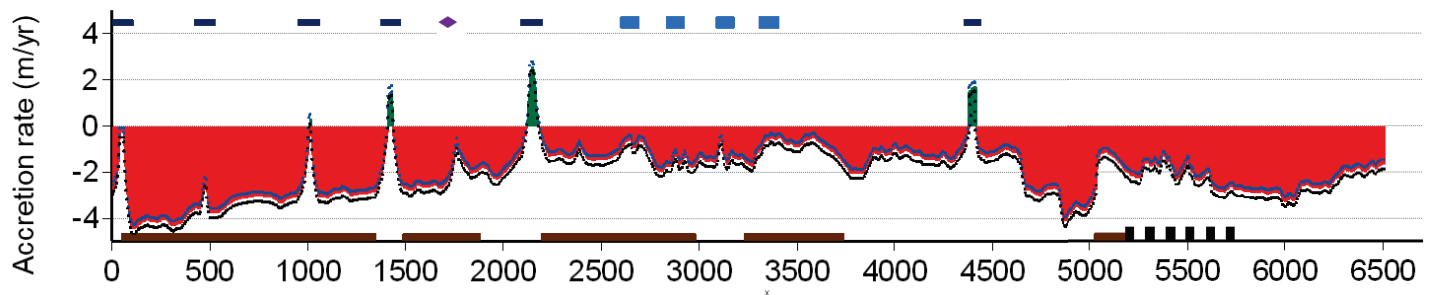

$\begin{array}{ll}\text { Length }(m) & \text { (h) } 2002.4-2017.1\end{array}$

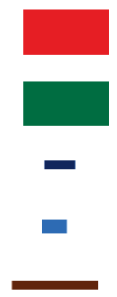

Erosion rate

Groin

Accretion rate

Detached breakwater

- Sunk ship-deck

Submerged breakwater

Revetments/

emergency rock dumping

(Continued) Figure 5: Annual rate of beach accretion between (e) December 17, 2013 and January 19, 2015 and, (f) January19, 2015 and January 13, 2016 (g) January 13, 2016 and January 12, 2017 (h) April 26, 2002 and January 12, 2017, with records of implementation of shoreline management measures in Marawila Beach

Figure 5-(a) shows the shoreline accretion rate between April 26, 2002, and December 29, 2005. The maximum accretion and erosion rates were $4.6 \mathrm{~m} / \mathrm{yr}$ and $5.5 \mathrm{~m} / \mathrm{yr}$, respectively. Shoreline management structures were not introduced during this period. Figure 5-(b) shows the shoreline accretion rate between December 29, 2005, and November 11, 2011, and the shoreline retreated from $40 \mathrm{~m}$ at the southern part of Marawila Beach (0-2100 m). Figure 5- 
(c) shows the shoreline accretion rate between November 11, 2011, and September 21, 2012, and an erosion rate of $40 \mathrm{~m} / \mathrm{yr}$ was observed along the beach stretch between $3000-$ $6000 \mathrm{~m}$, where most hotels are located. However, the beaches behind the detached breakwaters accreted at a rate of $25 \mathrm{~m} / \mathrm{yr}$. Figure 5-(f) presents the shoreline accretion rate between January 19, 2015, and January 13, 2016, and an accretion rate of $44 \mathrm{~m} / \mathrm{yr}$ were observed behind some of the detached breakwaters during this period.

Rubble mound revetments were installed to stabilize total $1.73 \mathrm{~km}$ of the beach. Three $80 \mathrm{~m}$ long detached breakwaters were constructed in 2011 to restore the beach at $-3.0 \mathrm{~m}$ low water of ordinary spring tides (LWOST). Figure 5-(d) shows the shoreline accretion rate between September 21, 2012, and December 17, 2013; 330,000 $\mathrm{m}^{3}$ of off-shore sand was pumped to nourish a $30 \mathrm{~m}$-wide area of the beach in September 2013, and the accretion between 2100-3800 m (1.7 km-long) resulted from beach nourishment. A $50 \mathrm{~m}$-long shipdeck was sunk between 1500 to $2000 \mathrm{~m}$ and a $60 \mathrm{~m}$-long submerged breakwater was constructed at $-4.0 \mathrm{~m}$ LWOST to sustain the nourished beach. Figure 5-(e) shows the shoreline accretion rate between December 17, 2013, and January 19, 2015. Three submerged breakwaters were constructed with $170 \mathrm{~m}$ between them, and a $170 \mathrm{~m}$-long revetment was observed near the $5000-5500$ m mark. Two detached breakwaters were constructed at 500 and $1000 \mathrm{~m}$ distance in 2015. Five $15 \mathrm{~m}$-long groins were constructed $100 \mathrm{~m}$ apart between 5200 - $5600 \mathrm{~m}$. Figure 5-(g) shows the shoreline accretion rate between January 13, 2016, and January 12, 2017. During February and December 2016, $801,344 \mathrm{~m}^{3}$ of sand was pumped to nourish $3.14 \mathrm{~km}$ of the beach. Sand with grain sizes $\left(d_{50}\right.$ value) ranging from 0.5 to $1.2 \mathrm{~mm}$ was extracted from the 12-m flat offshore mining area located $2 \mathrm{~km}$ from the Marawila Beach. The satellite image captured on January 12, 2017, only a portion of the total $3.14 \mathrm{~km}$ of beach nourishment. The accretion observed between $2100-4600 \mathrm{~m}$ ( $2.5 \mathrm{~km}$ long) was caused by beach nourishment. One detached breakwater (constructed at $4400 \mathrm{~m}$ ) and four submerged breakwaters were constructed to supplement the nourished area of the beach. Six groins were constructed next to the nourished beach downstream of the sediment flux to preserve the nourished sand that would have been transported by longshore drift. Figure 5-(h) shows the shoreline accretion rate between April 16,2002 , and January 12, 2017, and indicates that erosion was the dominant process in this period. However, owing to beach nourishment, the overall erosion at the central beach area was low.

Revetments, detached breakwaters, beach nourishment, submerged breakwaters, groins, and combinations of these structures were introduced as shoreline management measures at the end of February 2017. The revetments, breakwaters, and groins were protected with granite rock boulders (Figure 2). Revetments were installed to stabilize the eroded shoreline, while rocky materials were deployed at some rapidly eroding shorelines as an urgent protection measure before proper shoreline management structures were implemented. It was difficult to distinguish between revetments and emergency deployed rock in the satellite images. Continuous landward erosion was observed in some locations, even after stabilizing the shoreline; emergency rock deployment was conducted at these locations. Detached breakwaters, submerged breakwaters, and groins were installed to restore the shoreline by interrupting longshore drift and supplement nourished beaches.

Figure 6-(a) is a recent satellite image (image date: January 12, 2017) and Figure 6-(b) time axis. The area between 2100 and $5100 \mathrm{~m}$ consists of many hotels (see Figure 1). Firstly 
this area was protected from revetments during 2005 - 2011. Coastal managers have installed four submerged breakwaters instead revetments during 2012 and 2015 due to the strong resistance of hotel owners. However, those submerged breakwaters did not provide the intended protection and thus beach nourishment was introduced twice since 2013. The area between 5100 and 5700 was protected from a groin field having the objective to interrupt the movement of nourished sediments towards further north during the monsoon period.

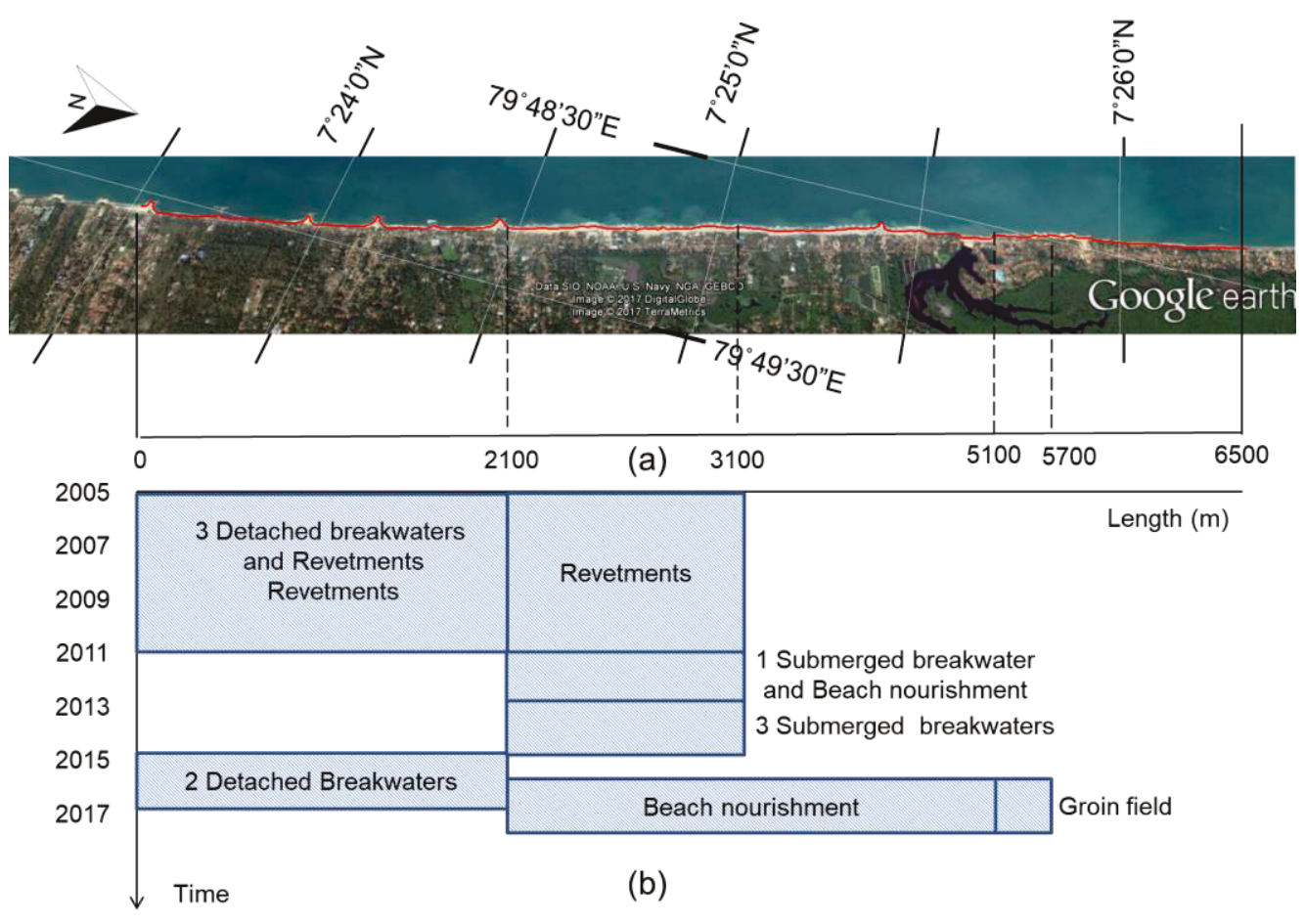

296

Figure 6: (a) Recent satellite image of Marawila beach (image date: January 12, 2017) (Source: Google Earth (Photo was taken by CNES/Airbus satellite) (b) the areas where the significant management initiatives have taken place along the time axis.

Table 1 shows the estimated accreted, eroded, and net accreted areas between the time periods marked by successive satellite images. Positive net accretion was only observed from January 13, 2016, to January 12, 2017, following sand nourishment. The estimated net eroded beach area from April 26, 2002, to January 12, 2017, was $174,000 \mathrm{~m}^{2}$ (17.4 ha). The lowest net erosion was observed from December 17, 2013, to January 19, 2015, following sand nourishment in September 2013. 
Table 1: Nourished volume estimated accreted, eroded and net accreted areas between the time periods of successive satellite images (Negative accreted area denotes eroded area)

\begin{tabular}{ccccccccc}
\hline Period & April 26, & December & November & September & December & January & January & April 26, \\
between & $2002-$ & $29,2005-$ & $11,2011-$ & $21,2012-$ & $17,2013-$ & 19,2015 & 13,2016 & $2002-$ \\
successive & December & November & September & December & January & - & - & January \\
images & 29,2005 & 11,2011 & 21,2012 & 17,2013 & 19,2015 & January & January & 26,2017 \\
& & & & & & 13,2016 & 26,2017 &
\end{tabular}

\begin{tabular}{|c|c|c|c|c|c|c|c|c|}
\hline $\begin{array}{l}\text { Nourished } \\
\text { volume } \\
\left(10^{3} \mathrm{~m}^{3}\right)\end{array}$ & & & & 330 & & & 801 & 1131 \\
\hline $\begin{array}{c}\text { Accreted } \\
\text { area }\left(10^{3} \mathrm{~m}^{2}\right)\end{array}$ & 11 & 5 & 8 & 22 & 9 & 8 & 68 & 131 \\
\hline $\begin{array}{l}\text { Eroded area } \\
\qquad\left(10^{3} \mathrm{~m}^{2}\right)\end{array}$ & 25 & 124 & 36 & 25 & 35 & 75 & 15 & 335 \\
\hline $\begin{array}{c}\text { Net accreted } \\
\text { area }\left(10^{3}\right. \\
\left.\mathrm{m}^{2}\right)\end{array}$ & -14 & -119 & -29 & -3 & -26 & -67 & 52 & -204 \\
\hline
\end{tabular}

\subsection{The effectiveness of shoreline protection measures}

The protected shoreline length per unit cost of each management measure (stabilized or restored) is presented in Table 2. The implementation costs of a 300-m revetment, an $80-\mathrm{m}$ detached breakwater, and nourishing a $2 \mathrm{~km}$-long $\times 30 \mathrm{~m}$-wide beach are approximately 18 , 24, and 670 million Sri Lankan Rupees (SLR) (approximately 4 million US dollar), respectively (CC\&CRMD, 2015, 2013). The tombolo width $(B)$ was considered as the length of the shoreline protected by detached breakwaters. However, the $B$ values differed between each of the detached breakwaters (Table 3), thus, the mean of all these values $(200 \mathrm{~m})$ was used to estimate the protected shoreline length per unit cost for detached breakwaters in Table 2.

\section{Table 2: Comparison of costs among shoreline management measures in Marawila Beach}

Shoreline management measure
The cost in million SLR (for given specification)

\section{Protected shoreline per unit cost}

m/ million SLR

\begin{tabular}{ccc}
\hline Revetment & $18(300 \mathrm{~m}$ long $)$ & 17 \\
\hline Detached breakwater & $23(80 \mathrm{~m}$ long $)$ & 9 \\
Beach nourishment & $640(2000 \mathrm{~m}$ long and $30 \mathrm{~m}$ wide $)$ & 3
\end{tabular}

Although revetments protect more of the beach area, detached breakwaters and beach nourishment measures were introduced to support fishing and recreational activities. Detached breakwaters are favoured by the fishing community as they can form a stable tombolo where they can land their small fishing boats. Based on the interviews carried out in February 2017, the fishermen also favour the deployment of a few more detached 
breakwaters if the tombolo is too narrow, which was reflected through the interviews. Some respondents remarked:

"We can easily land our fishing boats onto the resulting tombolo, even in the monsoon season. Sometimes there is not enough space when neighbouring fishing communities also land their boats due to beach erosion. [45 years old male fisherman who owned a $5 \mathrm{~m}$-long engine boat (February 14, 2017)]"

Five detached breakwaters were introduced to the southern Marawila Beach by coupling them to revetments (Figures 2-(b) and Figure 7) to optimize the cost. As the beach was nourished in December 2016, this section only discusses the effectiveness of the detached breakwaters. Figure 7 presents a diagram of three consecutive detached breakwaters. Taking CD as an arbitrary line along the revetments, $A$ denotes the beach area confined by the central lines of the neighboring detached breakwaters and line CD. $\Delta X$ is the distance between the consecutive center-lines. DB1, DB2, DB3, DB4, and DB5 indicate the detached breakwaters at $0,500,1000,1400$, and $2100 \mathrm{~m}$, respectively (Figure 5-(f)). DB2 and DB3 were constructed in 2015-2016; and DB1, DB4, and DB5 were constructed in 2010-2011. The left center-line of DB1 was marked between itself and the neighboring detached breakwater (located outside the case study area), and the right center-line of DB5 was marked between itself and the submerged breakwater (at $2900 \mathrm{~m}$ ). $B$ is the width of tombolo (or salient) bounded by the left and right center lines.

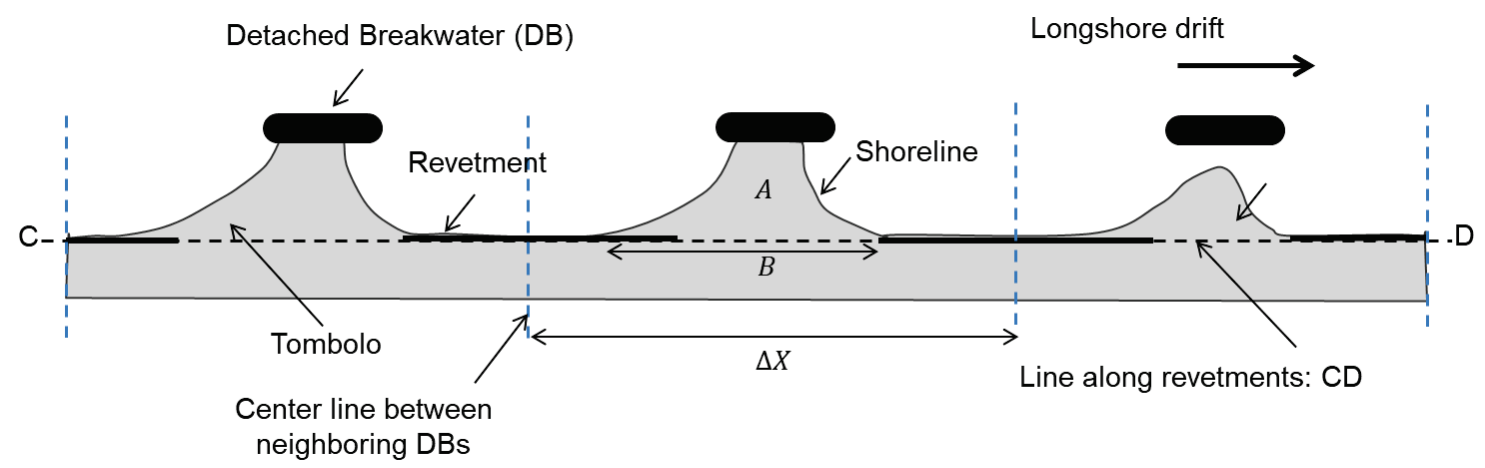

Figure 7: Schematic diagram of three consecutive detached breakwaters in Marawila South Beach. CD is an arbitrary line along revetments

Table 3 shows the width and area of the formed tombolos (or salients) of the detached breakwaters on the southern Marawila Beach on January 12, 2017. Smaller $A$ and $B$ values were observed at DB2 and DB3 as the formed salients had not yet developed into tombolos. The tombolo for DB5 was confined by the nourished beach on the right and the sunken shipdeck on the left, resulting in a relatively high $A$ value. 
Table 3: Width and area of formed tombolos (or salients) of detached breakwaters of Marawila South Beach on

\begin{tabular}{cccc}
\hline Detached Breakwater & $\boldsymbol{\Delta} \boldsymbol{X}(\mathrm{m})$ & $\boldsymbol{B}(\mathrm{m})$ & $\boldsymbol{A}\left(10^{3} \mathrm{~m}^{2}\right)$ \\
\hline DB1 & 350 & 220 & 6.1 \\
DB2 & 450 & 10 & 0.2 \\
DB3 & 400 & 130 & 2.7 \\
DB4 & 550 & 180 & 5.0 \\
DB5 & 450 & 450 & 11.4 \\
\hline
\end{tabular}

366

The beach was then nourished to achieve several goals: to slow the erosion that moved sediment downstream from the mouth of the Maha River at a rate of approximately 1-2 $\mathrm{km} / \mathrm{yr}$ (Wickramaarachchi, 2011); to create aesthetically appealing wide beaches, and to decrease salinization in coastal aquifers. Figure 8-(a)). The necessity of wide beaches was reflected by the interviews, and some respondents in the tourism sector remarked:

"Revetments and detached breakwaters diminished the aesthetic beauty of the coastline and narrowed the sunbathing area; some tourists complained and scolded us that we cheated them by posting fake photos of the beach on our webpage [34-year-old hotel worker at the reception desk of a 4-star hotel (February 15, 2017)]"

When the equilibrium beach profile was eventually formed on a nourished beach (Van der Wal, 1998; Verhagen, 1993), a 1-2 m steep drop (Figure 8-(b)) was formed by the erosive forces of waves and tides. Therefore, fishermen found it difficult to land their boats on the nourished beach.

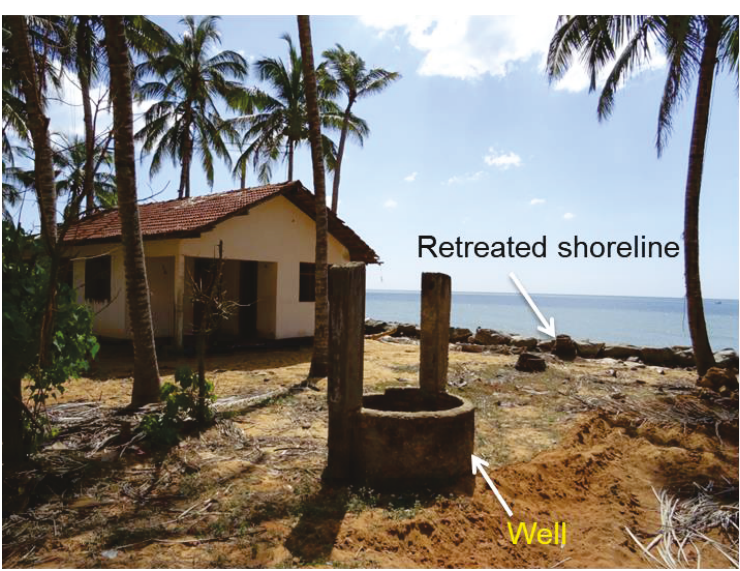

(a)

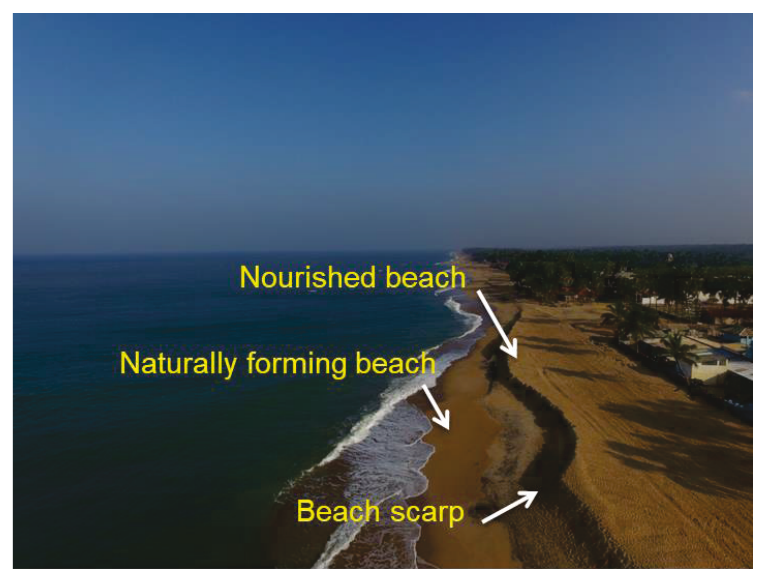

(b)

Figure 8: (a) An abundant coastal well due to salinization (Picture was taken on 13 February 2017) (b) Natural beach was forming on the nourished beach (Picture was taken on 16 February 2017) 
Figure 9-(a) shows the nearshore bathymetry in February 2007, and Figure 9-(b) shows the nearshore bathymetry in February 2017. Bathymetry maps were derived from the DEMs created from the 2017 and 2007 data sets. The arrow indicates the outlet of an ephemeral lagoon (Talwila Lagoon). Figure 9-(c) shows the change in bathymetry from 2007 to 2017. The term "change" here refers to the arithmetic difference between the DEMs of 2007 and 2017. Accretion areas are colored in red, and erosion areas are colored in blue. Nearshore erosion was predominant along the beach, including the nourished area.

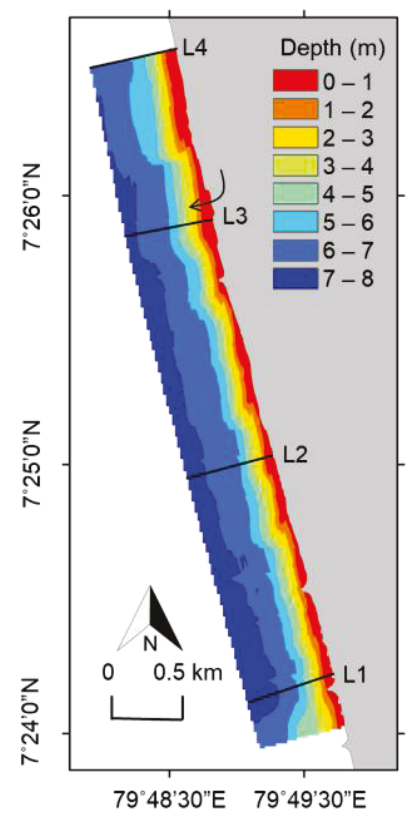

(a)

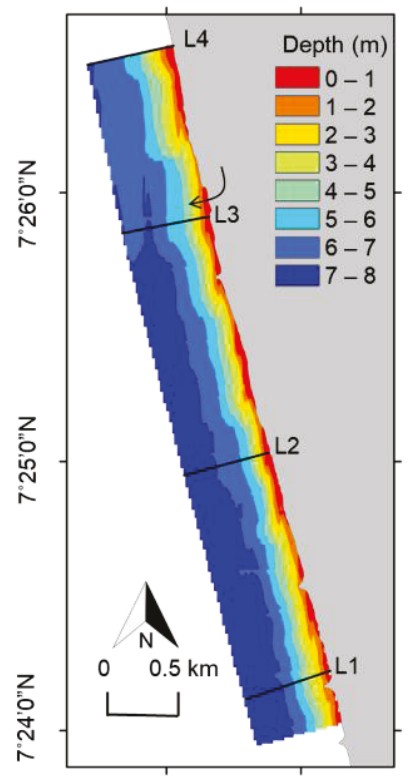

7948'30"E $\quad 7^{\circ} 949^{\prime} 300^{\prime \prime E}$ (b)

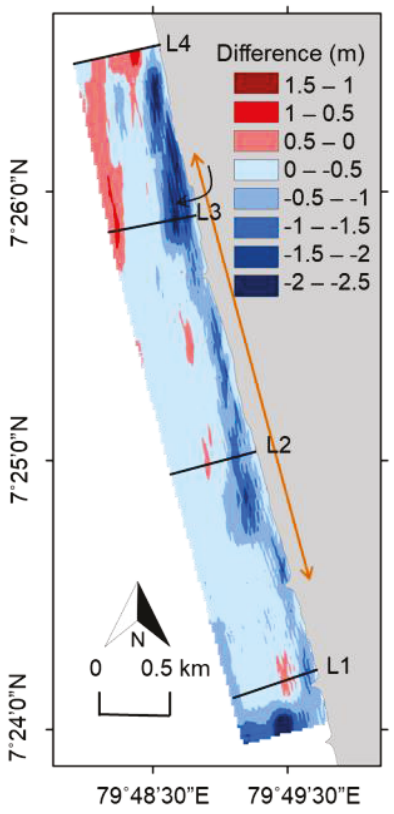

(c)

Figure 9: (a) Nearshore bathymetry of February 2007 (b) Nearshore bathymetry of February 2017 (c) Change in bathymetry

397

398

399

400

401

402

Figure 10 shows the cross-shore profiles of February 2007 and 2017 along lines L1, L2, L3, and L4. The shoreline was not managed via artificial structures in February 2007. Line L1 lies in front of the revetments, line L2 lies in front of the protected nourished beach; line L3 lies in front of the solely nourished beach, and line L4 lies in front of the untreated beach. Net erosion was observed between 2007 and 2017. 

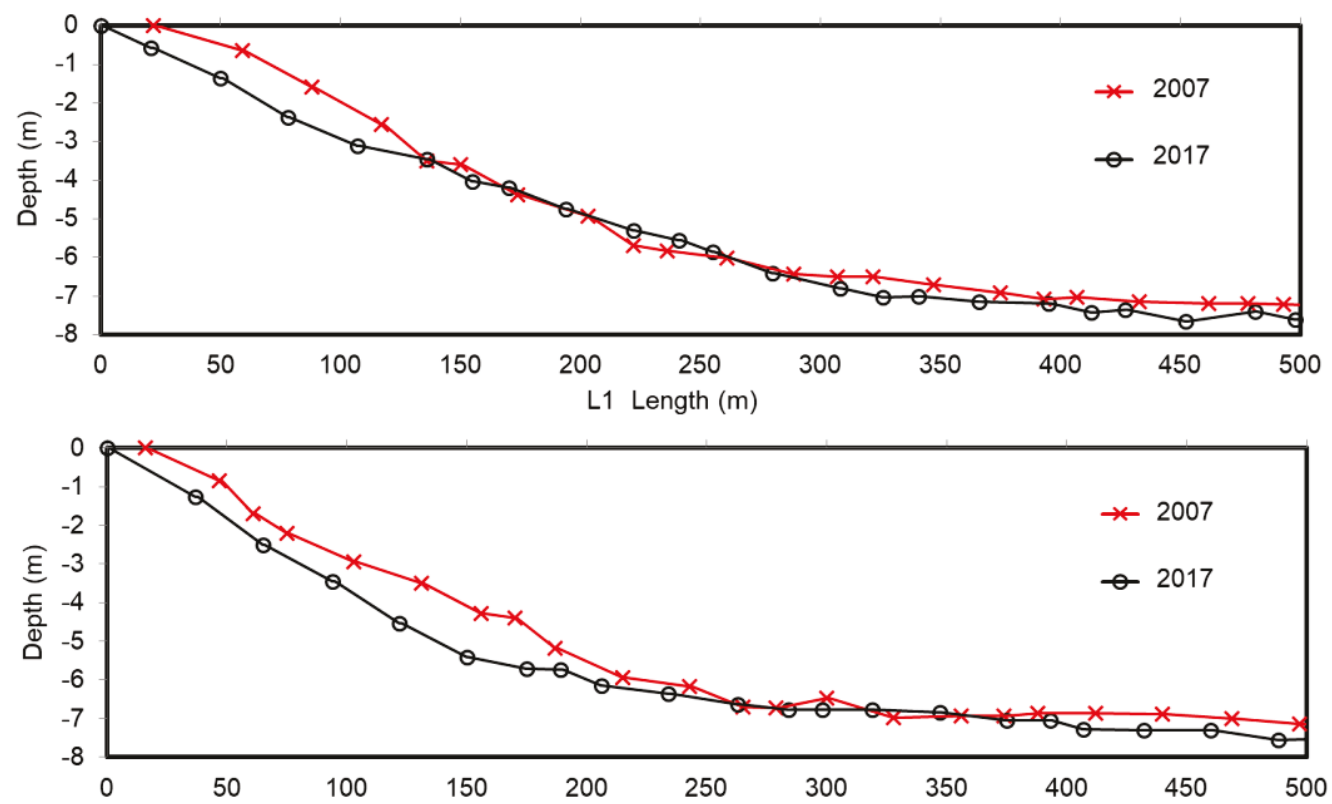

404

L2 Length $(m)$
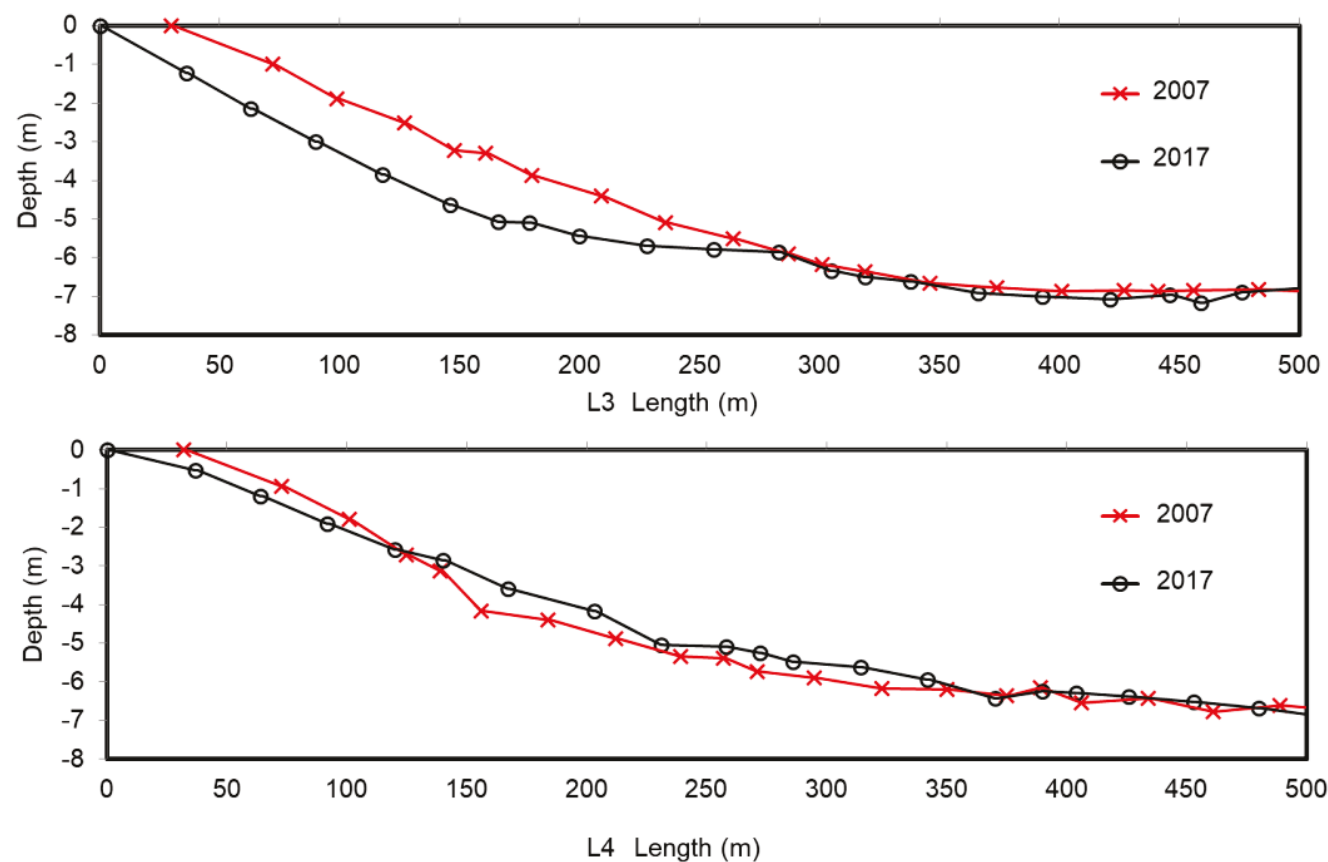

405

406

407

408

409

410

411

412

413

Figure 10: Cross-shore profiles of February 2007 and 2017 along line L1, L2, L3, and L4. Lines were shown in Figure 4-(b)

Figures 8 and 9 verify that significant erosion occurred during the last 10 years, which could have resulted from changes in wave climate during the decade, along with the anthropogenic causes. However, the assessment conducted in this study was strongly dependent on field observation, therefore, it would be interesting to further this study with a complementary numerical simulation of global operational analysis data (NCEP-FNL, for example) from a coastal engineering viewpoint. 


\section{Discussion}

\subsection{Socio-economic and environmental pressure on beach erosion between 1980 and 2002}

As the earliest clear satellite image with no cloud cover was captured on 26th April 2002, satellite image analysis began in 2002. The morphological status was observed from an analytical viewpoint after 2002, therefore, we discussed its historical context separately. This section describes the historical context of Marawila Beach between 1980 and 2002.

The sediment transport capacities of the western Sri Lankan coast was first estimated from the directional wave measurements of an off-coast pitch and roll wave buoy in 1990 (Fittschen et al., 1992; Sheffer and Frohle, 1991). These estimated sediment transport rates are still used to interpret shoreline evolution (Samarawikrama et al., 2009; Wickramaarachchi, 2012), even though they were observed three decades ago. A strong longshore current is generated due to monsoon wave regimes from south to north along the western coast of Sri Lanka (Dayananda, 1992). The estimated maximum longshore drift capacity is 1.1 million $\mathrm{m}^{3} / \mathrm{yr}$ (from south to north) during the south-west monsoon and 0.1 million $\mathrm{m}^{3} / \mathrm{yr}$ (from north to south) during the north-east monsoon. Marawila Beach erodes during the south-west monsoon and accretes during the north-east monsoon. A coastal cell within Marawila Beach is bounded by the mouths of the Maha and Daduru Rivers in the south and north. The 0.15 million $\mathrm{m}^{3} / \mathrm{yr}$ sand supply from the Maha River observed in 1984 was reduced below 0.05 million $\mathrm{m}^{3} / \mathrm{yr}$ in 2001 (CC\&CRMD, 2006). The increasing trend of erosion was caused by the reduction in the sediment supply from the Maha River.

The source of the Maha River is in the mountainous region of the central province of Sri Lanka, and it flows through five districts (Kandy, Matale, Kurunegala, Gampaha, and Puttalam). Hilly terrains and forests, smallholder tea and rubber plantations, and home gardens are found in the upstream region of the river, while large coconut plantations, rainfed paddy fields, clay and sand mines, tile and brick factories, and home gardens are found in the downstream area. This river serves as the northern boundary of the western province, which consumes $60 \%$ of Sri Lanka's total extracted sand. Annual sand mining increased from 0.111 million to 0.221 million $\mathrm{m}^{3} / \mathrm{yr}$ during 1984-1991 (Ranasinghe and Ranaweera Banda, 1991), and 23 million $\mathrm{m}^{3}$ of sand was extracted from the river during 1976-2001 (CC\&CRMD, 2006)

Progressive northwards erosion of $1 \mathrm{~m} / \mathrm{yr}$ between the mouth of the Maha River and Colombo was first observed in the early 1980s, and only local erosion cases have been observed at Marawila Beach (Godage, 1992). Progressive erosion crossed the river's mouth in the late 80s and reached Marawila Beach in 2001 (Dayananda, 1992; Godage, 1992; Wickramaarachchi, 2011).

\subsection{Government responses to mitigate beach erosion between 1980 and 2002}

Sand is the property of the state government and mining this resource requires permission from the Geological Survey Mining Bureau (GSMB) in accordance with the Sri Lankan Mines and Minerals Act No. 33 of 1992. Tenders for mining (or expressions of interest) are managed by regional administration offices (in this case, divisional sectaries (DS) offices). Sand mining is not well-monitored as, the two government agencies (GSMB and DS offices) operate with limited facilities and workforce (Kamaladasa, 2008a). 
Out of 15 key areas, Negombo Beach (see Figure 11-(a)) was identified as one threatened by erosion, and coast protection and stabilization measures were introduced in collaboration with the Danish International Development Agency (DANIDA) during 1986 to 1989. The project included $400,000 \mathrm{~m}^{3}$ of beach nourishment, and the deployment of four detached breakwaters and three groins in 1987 (Godage, 1992).

Bambukuliya Water Barrage (See Figure 11-(d)) was constructed across the Maha River in 1986 to prevent salinity (salt-water intrusion) intrusion. As a result, sediment supply to the river mouth was drastically reduced (Wickramaarachchi, 2011) and the caused 1-2 km/yr progressive northwards erosion; a slow rate was expected after the 1987 shoreline management activities. During the DANIDA project, 121 Million SLR was spent on coastal protection in 1986-1989, and the CCD later spent 150 Million SLR during 1990-2002.

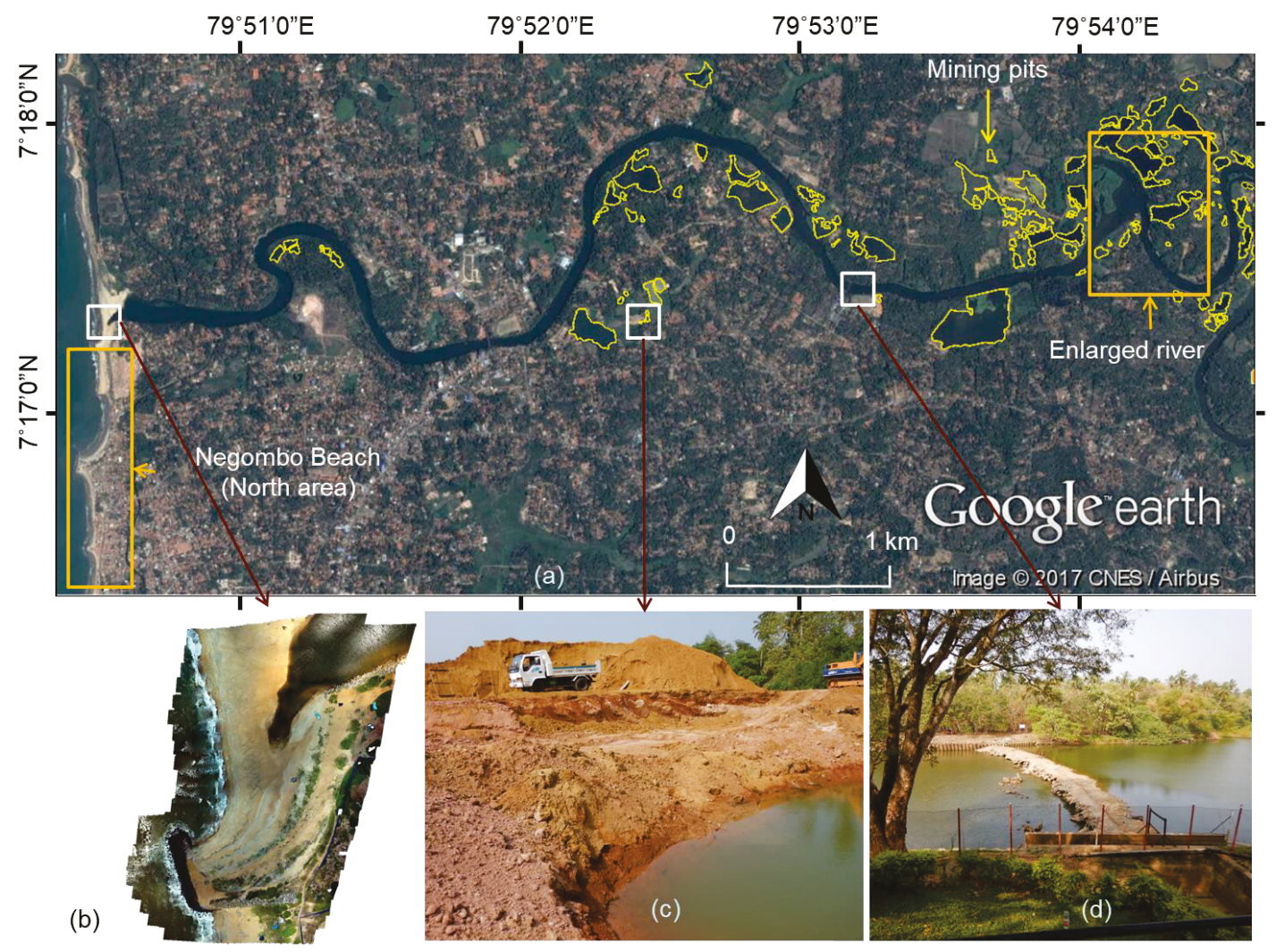

Figure 11: (a) Spatial extent of mining pits in the riparian area of Maha River (Image was taken on February 4, 2017) (Source: Google Earth (Photo was taken by CNES/Airbus satellite) (b) Maha River mouth is naturally closed by wave action evolving a sandbar (aerial view of August 17, 2017)(sources: we obtained through the photogrammetric processing of drone images) (c) Legally permitted mining site of clay and sand (d) No flow over a barrage which is located $7 \mathrm{~km}$ upstream from the river mouth (Photos (c) and (d) were taken on February 21, 2017))

4.3. Socio-economic and environmental pressure on beach erosion between 20022017

Although mechanized and artisan sand (or clay) mining was permitted within $100 \mathrm{~m}$ of both banks of the Maha River, as well as in the river channel, river banks, and the reservation, any form of mining activity, including mechanized and artisan, were prohibited by a Supreme Court case in 2004 (SCFR 81/2004). Currently, the government only permits artisan mining activities in the river and permits are only issued to miners who have traditionally engaged in 
this industry with a permit. The last revision to the CZMP in 2004 declared no mining zones in the river (Karunaratne, 2011). The strict regulation of sand mining from the river since 2004 has increased the price of a cube of sand from 1500 to 5500 SLR (Kamaladasa, $2008 \mathrm{~b})$. The increase in the price of sand encouraged and led to the creation of an uncontrolled, powerful "Sand Mafia" (Kamaladasa, 2008a).

Economic development in Sri Lanka was hindered during the armed civil conflict from July 23,1983 , to May 18,2008 . The government purchased many investments after the end of the armed conflict, thus promoting the construction industry and increasing sand demand. Large and small-scale manufactures of Calicut tiles and bricks mined sand in addition to clay from the riparian plains of the river. Some mining pits are directly adjoined to the river, while some are isolated under private ownership. Under these circumstances, the river expanded (Figure 11-(a)) in some places. Figure 11-(a) presents the spatial extent of mining pits in the riparian area surrounding the Maha River. Figure 11-(c) shows a legally permitted clay and sand mining site. Permission from GSMB is required to mine clay. The excavation depth should not exceed $7.62 \mathrm{~m}$ ( $25 \mathrm{ft}$.), and the mining pits should be restored in accordance with section 61(1) of the 1992 Mines and Minerals Act No 33 (amended by the 2006 Act No 66) (Karunaratne, 2011). However, these laws were not enforced, as reflected through the interviews. Some respondents remarked:

"Sand layers lie below clay, therefore, some miners dig deep pits. Depth cannot be seen after filling with water, but some pits are as deep as a grown coconut tree. [55-year-old male who owns a small brick-burning kiln (February 21, 2017)]"

We marked mining pits $15 \mathrm{~km}$ upstream along the river in an image from Google Earth Pro (see Figure 11-(a)), and their presence was confirmed during the fieldwork. A total of 1.4 million $\mathrm{m}^{2}$ (140 ha) of operating mining pits was observed in February 2017, which would greatly expand flooding and the water surface boundaries during the south-west monsoon season.

Figure 11-(b) presents an aerial image of the Maha River mouth, which was obtained through the photogrammetric processing of drone images. Figure 11-(b) shows the same area on August 17, 2017, and the river's mouth was closed by a sandbar due to an upstream drought. These pressures are imposed by water demand as well as drought; the water demand increased from 54 million $\mathrm{m}^{3}$ in 2005 to 66 million $\mathrm{m}^{3}$ in 2015, with drinking water constituting $54 \%$ out of the total water demand in the Maha River basin (Fernando, 2005). The government prioritizes the provision of drinking water and sanitation services, and dams (as for example Yatimahana Reservoir) will be constructed to restore potable water in the upstream river (Fernando, 2005; MM\&WD, 2017). (MM\&WD - Ministry of Megapolis and Western Development). As a result of increased water demand, water flow will be reduced to carry in Maha River.

\subsection{Government responses to mitigate beach erosion between 2002 and 2017}

The images of April 26, 2002, and December 29, 2005, were captured during shoreline erosion and accretion periods. Therefore, significant erosion is not depicted in Figure 5-(a) during 2002-2005. Northward littoral drift was bounded by the detached breakwaters (see Figure 5-(c)), resulting in successive erosion in downstream areas while the natural sediment supply decreased drastically. Submerged breakwaters and beach nourishment were successfully introduced to slow progressive erosion during 2013-2015 (see Figure 5- 

2016 (UN-OCHA, 2016, 2014), which may have accelerated the erosion of nourished sand.

529 The CRMP spent 1243 Million SLR on coastal protection between the Maha River mouth 530 and Marawila Beach during 2002-2006, and the CCD later spent 240 Million SLR during 2006-2010 (Wickramaarachchi, 2011). Over 1 billion SLR was invested to manage the Marawila shoreline during 2011-2017, which included the deployment of $2 \mathrm{~km}$-long revetments, six detached breakwaters, four submerged breakwaters, six groins, and 800,000 $\mathrm{m}^{3}$ of beach nourishment. Despite having all these hard engineering structures, continuous erosion remains to be the dominant trend of the study area. This could be linked to the present context of sea level rise, increased frequency of tropical storms, storm surges etc as the products of recent climate change. Recently observed wave climate data are limited for Marawila and numerical simulation of reanalysis data (such as NCEP-FNL) could be viable. However, such calculations are outside the scope of the present research, though such a problem warrants further investigation.

Figure 12-(a) shows the cumulative shoreline accretion relative to the shoreline in 2002, and Figure 12-(b) shows the cumulative cost of the adaptive measures. Sand nourishment in 2013 and 2017 significantly reduced erosion. There was a heavy storm condition in early November 2015 (DMC, 2015) and this could be a one of a reason for the relatively high erosion in 2016.
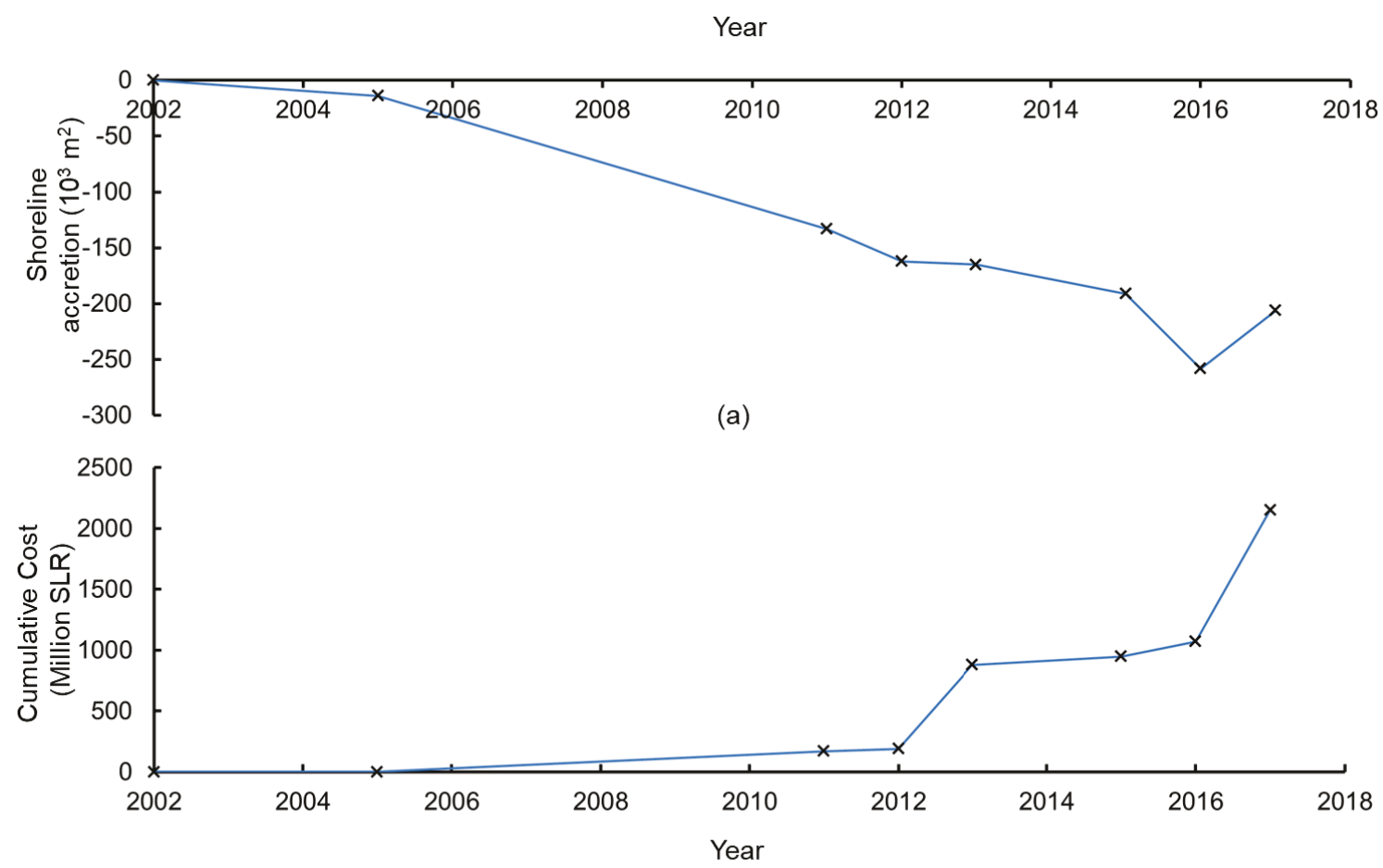

(b)

Figure 12: (a) Cumulative shoreline accretion relative to the shoreline in 2002; (b) Cumulative cost of adapted measures from $2002-2017$

Table 4 summarizes the chronological shoreline change, major causes, adopted measures, and the reasons for these measures. The southern, central, and northern beaches stretch from 0-1200, 1200-5100, and 5100-6100 m along Marawila Beach, respectively. Table 4: 


\begin{tabular}{|c|c|c|c|c|}
\hline Year & $\begin{array}{l}\text { Change in } \\
\text { shoreline }\end{array}$ & Major Causes & $\begin{array}{l}\text { Adapted measures } \\
\text { (location) }\end{array}$ & $\begin{array}{l}\text { Reasons for each } \\
\text { adaptation measures }\end{array}$ \\
\hline \multirow{2}{*}{$\begin{array}{l}2005- \\
2011\end{array}$} & \multirow{2}{*}{$\begin{array}{l}\text { South beach } \\
\text { retreated }\end{array}$} & $\begin{array}{l}\text { 1. Reduction of sediment } \\
\text { supply from Maha } \\
\text { River } \\
\text { Sediment }\end{array}$ & $\begin{array}{l}1.73 \mathrm{~km} \text { of revetments } \\
\text { (south beach) }\end{array}$ & Low-cost measure \\
\hline & & $\begin{array}{l}\text { River } \\
\text { Sediment } \\
\text { accumulation at } \\
\text { upstream shore } \\
\text { protection measures }\end{array}$ & $\begin{array}{l}3 \text { detached } \\
\text { breakwaters (south } \\
\text { beach) }\end{array}$ & $\begin{array}{l}\text { To provide anchoring place } \\
\text { to nearshore fishing boats }\end{array}$ \\
\hline $\begin{array}{l}2011- \\
2012\end{array}$ & $\begin{array}{l}\text { Erosion was } \\
\text { propagated to } \\
\text { central beach }\end{array}$ & $\begin{array}{ll}\text { 1. } & \text { Reduction of sediment } \\
\text { supply from Maha } \\
\text { River } \\
\text { 2. Sediment } \\
\text { accumulation at } \\
\text { detached breakwaters }\end{array}$ & $\begin{array}{l}0.30 \mathrm{~km} \text { of revetments } \\
\text { (central beach) }\end{array}$ & Low-cost measure \\
\hline \multirow{2}{*}{$\begin{array}{l}2012- \\
2013\end{array}$} & \multirow{2}{*}{$\begin{array}{l}\text { The central beach } \\
\text { was accreted }\end{array}$} & \multirow{2}{*}{$\begin{array}{l}\text { Reduction of sediment } \\
\text { supply from Maha } \\
\text { River } \\
\text { Sediment } \\
\text { accumulation at } \\
\text { detached breakwaters }\end{array}$} & $\begin{array}{l}1 \text { Submerged } \\
\text { breakwaters (central } \\
\text { beach) }\end{array}$ & $\begin{array}{l}\text { 1. To bypass some } \\
\text { sediments at the } \\
\text { breakwater } \\
\text { 2. For aesthetic appealing } \\
\text { of recreational (central) } \\
\text { beach }\end{array}$ \\
\hline & & & $\begin{array}{l}330,000 \mathrm{~m}^{3} \text { of beach } \\
\text { nourishment (central } \\
\text { beach) }\end{array}$ & $\begin{array}{l}\text { 1. To retard the } \\
\text { continuation of erosion } \\
\text { toward the north } \\
\text { To restore aesthetically } \\
\text { appealing wide beaches } \\
\text { (central) }\end{array}$ \\
\hline $\begin{array}{l}2013- \\
2015\end{array}$ & $\begin{array}{l}\text { The central beach } \\
\text { was eroded }\end{array}$ & $\begin{array}{l}\text { 1. Reduction of sediment } \\
\text { supply from Maha } \\
\text { River } \\
\text { 2. Several tropical storms }\end{array}$ & $\begin{array}{l}3 \text { Submerged } \\
\text { breakwaters (central } \\
\text { beach) }\end{array}$ & $\begin{array}{l}\text { 1. To bypass some } \\
\text { sediments at the } \\
\text { breakwater } \\
\text { To aesthetic appealing } \\
\text { of recreational (central) } \\
\text { beach } \\
\text { 3. To supplement } \\
\text { nourished beach }\end{array}$ \\
\hline \multirow[t]{2}{*}{$\begin{array}{l}2015- \\
2016\end{array}$} & \multirow[t]{2}{*}{$\begin{array}{l}\text { Erosion was } \\
\text { propagated to north } \\
\text { beach }\end{array}$} & \multirow[t]{2}{*}{$\begin{array}{l}\text { 1. Reduction of sediment } \\
\text { supply from Maha } \\
\text { River } \\
\text { 2. Several tropical storms }\end{array}$} & $\begin{array}{l}3 \text { detached } \\
\text { breakwaters (south } \\
\text { beach) }\end{array}$ & $\begin{array}{l}\text { 1. To restore south beach } \\
\text { area (Because central } \\
\text { beach was already } \\
\text { nourished) } \\
\text { 2. To provide anchoring } \\
\text { place to nearshore } \\
\text { fishing boats }\end{array}$ \\
\hline & & & 5 groins (north beach) & $\begin{array}{l}\text { To supplement beach } \\
\text { nourishment }\end{array}$ \\
\hline \multirow{3}{*}{$\begin{array}{l}2016- \\
2017\end{array}$} & \multirow{3}{*}{$\begin{array}{l}\text { The central beach } \\
\text { was accreted }\end{array}$} & \multirow{3}{*}{$\begin{array}{l}\text { Reduction of sediment } \\
\text { supply from Maha River }\end{array}$} & $\begin{array}{l}801,000 \mathrm{~m}^{3} \text { of beach } \\
\text { nourishment (central } \\
\text { beach) }\end{array}$ & $\begin{array}{l}\text { 1. To retard the } \\
\text { continuation of erosion } \\
\text { toward the north } \\
\text { 2. To restore aesthetically } \\
\text { appealing wide beaches } \\
\text { (central) }\end{array}$ \\
\hline & & & 1 groin (north beach) & $\begin{array}{l}\text { To supplement beach } \\
\text { nourishment }\end{array}$ \\
\hline & & & $\begin{array}{l}1 \text { detached } \\
\text { breakwater (central } \\
\text { beach) }\end{array}$ & $\begin{array}{l}\text { 1. To supplement beach } \\
\text { nourishment } \\
\text { To provide anchoring } \\
\text { place to nearshore } \\
\text { fishing boats }\end{array}$ \\
\hline
\end{tabular}


554 Coastal erosion is a common problem in many coastal countries. We reviewed the coastal management practices in other developing countries of similar landforms and discussed the similarities and differences of their management practices. We reviewed shoreline management practices in India, Indonesia, Malaysia, Vietnam, and the Philippines. Enactment of regulations, the establishment of management data bases and conflicting laws in different administration levels were the most common challenges in effective shoreline management (Cuong and Cu, 2014; Nayak, 2017; White et al., 2006). The coastal regions in these countries are regularly affected by cyclones and storm surges and as a result awareness of the importance of coastal management is raised among numerous stakeholders. Marine and coastal management institutes in Malaysia, Indonesia and Philippines are encouraging community-based shoreline management approaches(Siry, 2006; White et al., 2006). The difference in the Sri Lankan case was that the Locals, community representatives, coastal managers, and government administration officers need to act on a participatory basis before introducing a particular management strategy. Subang Indonesia (Kikuyama et al., 2017), Cai River mouth in NHA Trang Vietnam (Kobayashi et al., 2017), Southwest coast of India (Noujas and Thomas, 2015) etc. are recently observed erosion hotpots and these complex cases emphasize the necessity of management lessons from different type of erosion problems.

\section{Conclusions}

The socio-economic and environmental problems associated with the beach erosion are deeply linked. This study aimed to abstract and reify the morphological and socio-economic perspectives of an adaptively managed coastal erosion problem, and its findings illustrate the coastal erosion problem holistically. We found that the development pressure of the construction industry, population, and weak institutional coordination to regulate sand (and clay) mining in the riparian area of the Maha River causes severe erosion of the Marawila Beach. In addition, changes in the river system not only result in coastal erosion but also conflicts between different stakeholders. Anthropogenic activities in the Maha River basin have a high potential to reduce future sediment supply by this river. The estimated net eroded beach area during 2002 - 2017 is 17.4 ha. Revetments, detached breakwaters, submerged breakwaters, beach nourishment, groins, and combinations of these measures were chronologically adapted (see Table 4) to mitigate coastal erosion. By briefly examining the historical changes in the shoreline management of the Marawila Beach, we concluded that Maha River flow conditions of the early 80 s cannot be returned. Therefore, the solution can be only achieved through shoreline management and beach nourishment could be one of its vital measures. The shoreline analysis was revealed that the beach recovery from the sand nourishment (beach nourishment) was short-lived. This could be a result of the use of offshore fine sand deposits. Continuous beach nourishment, along with the deployment of detached breakwaters, would be an acceptable solution for both the tourism and fishing sectors. However, the implementation of such a project requires a large investment that may not be easily provided in a developing country such as Sri Lanka. Shoreline management by dividing shoreline into several zones based on its use would be the possible cost-effective alternatives for reducing the coastal vulnerability to erosion. As an example, beach nourishment is only implemented in where tourist hotels are located and detached breakwaters in other areas. Another trial solution is to replace Bambukuliya water barrage (the concrete weir) from a shell-type roller gate which could prevent saltwater intrusion and allow sediment to pass through. Cost-benefit evaluation of shoreline management scenarios 
600

601

602

603

604

605

606

607

608

609

610

611

612

613

614

615

616

617

618

619

620

621

622

623

624

625

626

627

628

629

630

631

632

633

634

635

636

637

638

639

640

641

is recommended to consider feasible measures for increasing the sustainability of coastal communities.

\section{Acknowledgment:}

This study was partially funded by JSPS KAKENHI Grant No. 25303016 and Newton Fund UK awarded to the University of East London.

\section{Reference}

Bastiaanssen, W., Chandrapala, L., 2003. Water balance variability across Sri Lanka for assessing agricultural and environmental water use. Agric. Water Manag. 58, 171-192. doi:10.1016/S0378-3774(02)00128-2

CC\&CRMD, 2015. Overview Coast Conservation and Coastal Resource Management Department [WWW Document]. Coast Conserv. Coast. Resour. Manag. Dep. Sri Lanka Web Page. URL

http://www.coastal.gov.lk/index.php?option=com_content\&view=article\&id=109\&ltemid= 57\&lang=en (accessed 10.24.17).

CC\&CRMD, 2013. Marawila beach nourishment project - Phase I [WWW Document]. Complet. Proj. URL

http://www.coastal.gov.lk/index.php?option=com_content\&view=article\&id=121\&ltemid= 112\&lang=en (accessed 10.24.17).

CC\&CRMD, 2006. Coastal Zone Management Plan (CZMP) 2004 [WWW Document]. Gaz. Extraordinary Part I Sec Gaz. Extraordinary Democr. Social. Repub. Sri Lanka 2006. URL http://www.coastal.gov.Ik/downloads/pdf/CZMP English.pdf (accessed 10.9.17).

Chandramohan, P., Nayak, B.U., Raju, V.S., 1990. Longshore-transport model for south Indian and Sri Lankan coasts. J. Waterw. Port, Coastal, Ocean Eng. 116, 408-424.

Cuong, N.Q., Cu, N. Van, 2014. Integrated Coastal Management in Vietnam : Current Situation and Achievements of Integrated. J. Mar. Sci. Technol. 14, 89-96.

Dayananda, H. V, 1992. Shoreline Erosion in Sri Lanka's Coastal Areas. Coast Conservation Department, Colombo,Sri Lanka.

DCS, 2012a. Puttalam District Population Distribution by DS Division [WWW Document]. Census Popul. Hous. 2012 North West. Prov. URL http://www.statistics.gov.Ik/PopHouSat/CPH2011/index.php?fileName=NWP\&gp=Activit ies\&tpl=3 (accessed 12.18.17).

DCS, 2012b. Population by religion according to districts, 2012 [WWW Document]. Sri Lanka Census Popul. Housing, 2011. URL

http://www.statistics.gov.lk/PopHouSat/CPH2011/index.php?fileName=pop43\&gp=Activ ities\&tpl=3 (accessed 12.19.17).

De Vos, A., Pattiaratchi, C.B., Wijeratne, E.M.S., 2014. Surface circulation and upwelling patterns around Sri Lanka. Biogeosciences 11, 5909-5930. doi:10.5194/bg-11-59092014

DMC, 2015. Daily situation report Sri Lanka - November 2015, Disaster Management centre, Sri Lanka. Colombo,Sri Lanka.

DoM, 2016. Climate of Sri Lanka [WWW Document]. Dep. Meteorol. URL http://www.meteo.gov.lk/index.php?option=com_content\&view=article\&id=94\&ltemid=3 
Fernando, K.M.F.S., 2005. Maha oya ( river ) \& river basin from national drinking water \& sanitation service providers perspective [WWW Document]. NARBO (Network Asian River Basin Organ. URL http://www.narbo.jp/data/01_events/materials/tc02_2_10.pdf

Fittschen, T., Perera, J.A.S.C., Scheffer, H.., 1992. Sediment transport study for the Southwest Coast of Sri Lanka. Colombo,Sri Lanka.

Godage, D., 1992. Coast Erosion Management Plan and It's Implementation, in: Scheffer, H.. (Ed.), Seminar on Causes of Coastal Erosion in Sri Lanka. CCD/GTZ Coast Conservation Project, Colombo,Sri Lanka, pp. 323-330.

Gunaratna, P.P., Ranasinghe, D.P.L., Sugandika, T.A.N., 2011. Assessment of nearshore wave climate off the Southern Coast of Sri Lanka. Engineer 44, 33-42. doi:10.4038/engineer.v44i2.7021

Kamaladasa, B., 2008a. Issues and challenges in river management due to excessive sand mining. River Symp. - Int. Water Cent.

Kamaladasa, B., 2008b. Issues and challenges in river management river management due to excessive sand mining due to excessive sand mining in Sri Lanka in Sri Lanka [WWW Document]. 15th Int. River Symp. URL http://archive.riversymposium.com/papers08/Badra Kamaladasa.pdf (accessed 1.1.17).

Karunaratne, W., 2011. Impacts of Sand and Clay Mining on the Riverine and Coastal Ecosystems of the Maha Oya: Legal and Policy Issues and Recommendations. Colombo,Sri Lanka.

Kikuyama, S., Suzuki, T., Sasaki, J., Achiari, H., Soendjoyo, S.A., Higa, H., Wiyono, A., 2017. A Study on Coastal Erosion and Deposition Processes in Subang, Indonesia, in: Asian and Pacific Coasts 2017. WORLD SCIENTIFIC, pp. 503-514. doi:10.1142/9789813233812_0046

Klein, R.J.T., Smit, M.J., Goosen, H., Hulsbergen, C.H., 1998. Resilience and vulnerability: Coastal dynamics or Dutch dikes? Geogr. J. 164, 259-268. doi:10.2307/3060615

Kobayashi, A., Uda, T., Noshi, Y., 2017. Erosion of Cai River Mouth in Nha Trang, Vietnam, in: Asian and Pacific Coasts 2017. WORLD SCIENTIFIC, pp. 548-559. doi:10.1142/9789813233812_0050

MM\&WD, 2017. Western Region Megapolis Planning Project [WWW Document]. Minist. Megap. West. Dev. URL https://www.wko.at/service/aussenwirtschaft/western-regionmegapolis.pdf (accessed 10.10.17).

Nayak, S., 2017. Coastal zone management in India - present status and future needs. Geo-Spatial Inf. Sci. 20, 174-183. doi:10.1080/10095020.2017.1333715

Noujas, V., Thomas, K.V., 2015. Erosion Hotspots along Southwest Coast of India. Aquat. Procedia 4, 548-555. doi:10.1016/j.aqpro.2015.02.071

Paganelli, D., La Valle, P., Ercole, S., Teofili, C., Nicoletti, L., 2013. Assessing the impacts of coastal defense structures on habitat types and species of European interest (92/43/EC): a methodological approach. J. Coast. Res. 1009-1014. doi:10.2112/SI65171.1

Panagos, P., Jones, A., Bosco, C., Kumar, P.S.S., 2011. European digital archive on soil maps (EuDASM): preserving important soil data for public free access. Int. J. Digit. 
Pathirage, J., Collyer, M., 2011. Capitalizing social networks: Sri Lankan migration to Italy. Ethnography 12, 315-333. doi:10.1177/1466138110362013

Perera, H.N.., 1990a. Need for review and upgrading of master plan for coast erosion management, in: Sheffer, H.J. (Ed.), Seminar on Causes of Coastal Erosion in Sri Lanka. CCD/GTZ Coast Conservation Project, Colombo,Sri Lanka, pp. 331-348.

Perera, H.N.., 1990b. Need for review and upgrading of master plan for coast erosion management, in: Sheffer, H.J. (Ed.), Seminar on Causes of Coastal Erosion in Sri Lanka. CCD/GTZ Coast Conservation Project, Colombo, Sri Lanka, pp. 331-348.

Ranasinghe, I., Ranaweera Banda, R.M., 1991. Monitoring Resources Utilization and their impacts in the Coastal Zone, in: Sheffer, H.J. (Ed.), Seminar on Causes of Coastal Erosion in Sri Lanka. CCD/GTZ Coast Conservation Project, Colombo,Sri Lanka, pp. 269-288.

Ratnasooriya, H.A.R., Samarawickrama, S.P., Imamura, F., 2007. Post Tsunami Recovery Process in Sri Lanka. J. Nat. Disaster Sci. 29, 21-28. doi:10.2328/jnds.29.21

Roebeling, P., Coelho, C., Reis, E., 2011. Coastal erosion and coastal defense interventions : a cost-benefit analysis. J. Coast. Res. 1415-1419.

Samarasekara, R.S.M., Sasaki, J., Esteban, M., Matsuda, H., 2017. Assessment of the cobenefits of structures in coastal areas for tsunami mitigation and improving community resilience in Sri Lanka. Int. J. Disaster Risk Reduct. 23, 80-92. doi:10.1016/j.jjdrr.2017.04.011

Samarawikrama, S.P., Costa, W.A.J., Dissanayaka, D.M.B., Dulshan, P.R.., 2009. Coastal Erosion Management in Sri Lanka. Moratuwa, Sri Lanka.

Sheffer, H.J., Frohle, P., 1991. Results of directional wave measurement off Galle, in: Scheffer, H.. (Ed.), Seminar on Causes of Coastal Erosion in Sri Lanka. Coast Conservation Department, Colombo,Sri Lanka, pp. 75-97.

Siry, H.Y., 2006. Decentralized coastal zone management in Malaysia and Indonesia: A comparative perspective. Coast. Manag. 34, 267-285. doi:10.1080/08920750600686679

Turner, R.K., Lorenzoni, I., Beaumont, N., Bateman, I.J., Langford, I.H., McDonald, A.L., 1998. Coastal Management for Sustainable Development: Analysing Environmental and Socio-Economic Changes on the UK Coast. Geogr. J. 164, 269-281. doi: $10.2307 / 3060616$

Uda, T., 2017. Japan's Beach Erosion: Reality and Future Measures. World Scientific.

UN-OCHA, 2016. Sri Lanka: Floods and Landslides Situation Report No. 1 (as of 22 May 2016) [WWW Document]. UN Off. Coord. Humanit. Aff. URL https://reliefweb.int/report/sri-lanka/sri-lanka-floods-and-landslides-situation-report-no-122-may-2016 (accessed 1.7.18).

UN-OCHA, 2014. Sri Lanka: Floods and Landslides - Jun 2014 [WWW Document]. UN Off. Coord. Humanit. Aff. URL https://reliefweb.int/disaster/fl-2014-000070-Ika (accessed 1.7.17).

UNSL, 2015. Sri Lankan Migrant Domestic Workers - The Impact of Sri Lankan Polices on Workers' Right to Freely Access Employment [WWW Document]. URL 
http://lk.one.un.org/wp-content/uploads/2016/05/Study-on-Sri-Lankan-MigrantDomestic-Workers.pdf

Van der Wal, D., 1998. The impact of the grain-size distribution of nourishment sand on aeolian sand transport. J. Coast. Res. 620-631.

Verhagen, H.J., 1993. Method for artificial beach nourishment, in: Coastal Engineering 1992. pp. 2474-2485.

Verstappen, H.T., Hoschtitzky, M.E.D., 1987. Geomorphological Map of Sri-Lanka [WWW Document]. ITC, Enschede. URL https://esdac.jrc.ec.europa.eu/content/geomorphological-map-sri-lanka (accessed 8.15.18).

Walters, C., 1997. Challenges in adptative management of riparian and coastal ecosystems. Conserv. Ecol. 1. doi:10.1111/j.1526-100X.2008.00478.x

White, A., Deguit, E., Jatulan, W., Eisma-Osorio, L., 2006. Integrated coastal management in Philippine local governance: Evolution and benefits. Coast. Manag. 34, 287-302. doi:10.1080/08920750600686687

Wickramaarachchi, B., 2012. Hazard Profiles of Sri Lanka. Ministry of Disaster Management, Sri Lanka, Colombo,Sri Lanka.

Wickramaarachchi, B., 2011. Spatial Analysis \& Mapping, Maha Oya Lowland Corridor. Colombo,Sri Lanka.

Williams, B.K., Szaro, R.C., Shapiro, C.D., 2009. What is Adaptive Management. Adapt. Manag. US Dep. Inter. Tech. Guid. 1-7. doi:10.4159/harvard.9780674420540.c13 